MAKING DENSITY WORK: TALL BUILDINGS IN DOWNTOWN TORONTO

\author{
Colin James Wolfe \\ BA, University of Winnipeg, 2008 \\ A Major Research Paper \\ Presented to Ryerson University \\ In partial fulfillment of the requirements for the degree of \\ Master of Planning \\ In \\ Urban Development
}

Toronto, Ontario, Canada, 2014

(C)Colin James Wolfe, 2014 


\section{AUTHOR'S DECLARATION}

I hereby declare that I am the sole author of this major research paper. This is a true copy of the major research paper, including any required final revisions, as accepted by my examiners. I authorize Ryerson University to lend this major research paper to other institutions or individuals for the purpose of scholarly research

I further authorize Ryerson University to reproduce this major research paper by photocopying or by other means, in total or in part, at the request of other institutions or individuals for the purpose of scholarly research.

I understand that my major research paper may be made electronically available to the public. 


\title{
MAKING DENSITY WORK: TALL BUILDINGS IN DOWNTOWN TORONTO
}

\author{
(C)Colin Wolfe, 2014 \\ Master of Planning \\ In \\ Urban Development \\ Ryerson University
}

\begin{abstract}
Urban growth and change in Downtown Toronto is proceeding at an unprecedented rate. While this is indicative of a robust economic climate and a vibrant streetscape, the pace of this development presents a host of challenges to City of Toronto as it attempts to maintain a high quality of life for its residents. This discussion considers quality of life in the context of growth related pressure Downtown Toronto at three different scales, flowing from resident priorities expressed in two recent surveys of residents in high-density communities. Using a mixed methods research approach, primary survey data is complemented with key informant interviews. Discussion touches on issues of small living spaces, a perceived lack of diversity in housing options, the need for public realm enhancement, and the potential of the Development Permits System as an alternative planning framework to improve quality of life for current and future Downtown residents.
\end{abstract}

Key Words:

quality of life; density; amenity spaces; public realm; planning frameworks 


\section{Table of Contents}

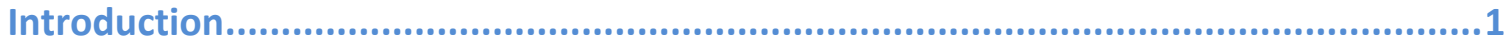

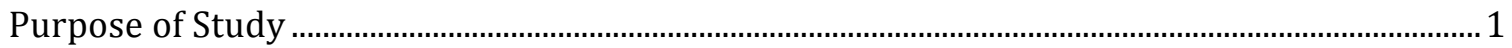

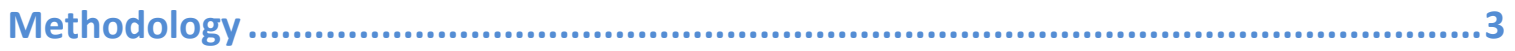

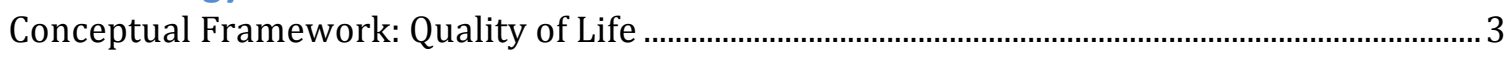

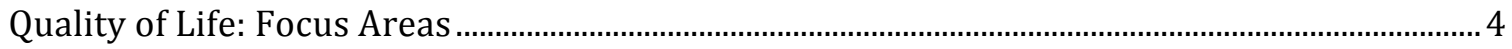

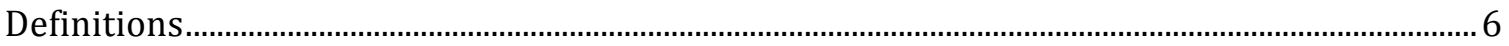

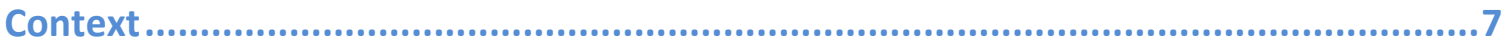

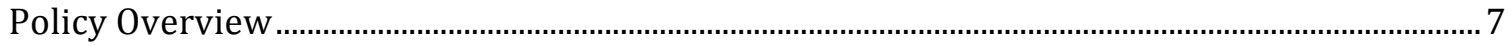

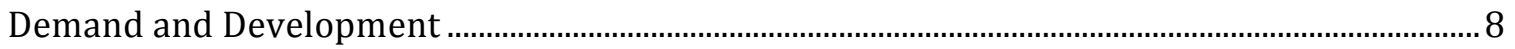

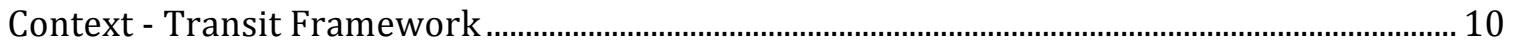

Section 1: Life Inside the Building - Residents and Quality of Life..........................12

Quality of Life Indicator: Small Unit Sizes ........................................................................................... 13

Section 1.A: Small Unit Sizes and Common Spaces .................................................................... 14

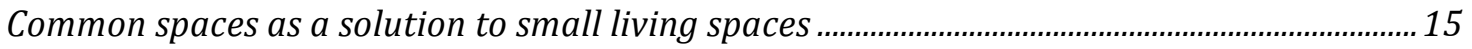

Section 1.A: Innovative approaches to indoor common spaces .................................................19

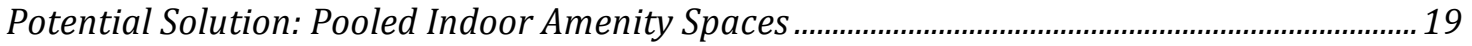

Challenges: Pooled Amenity Spaces ............................................................................................... 23

Common Spaces as a Solution to Small Living Spaces - Summary …….........................................24

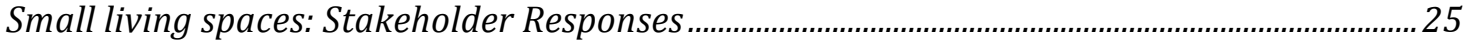

Section 1B: A range of housing as a solution to small living spaces .............................................. 27

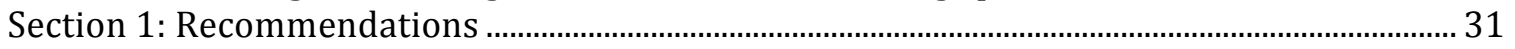

Section 2: Life Around the Building - The Public Realm and Quality of Life...............33

Quality of Life Indicator: The Importance of Walking ........................................................................... 33

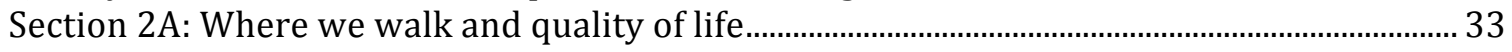

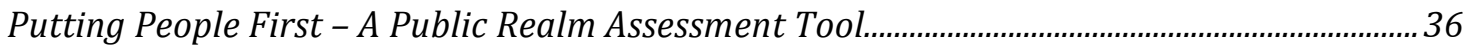

The Public Realm Assessment Tool and Quality of Life ................................................................... 36

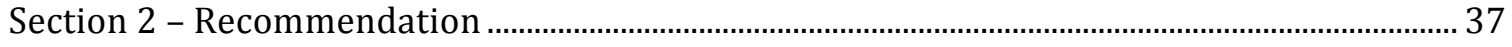

Section 3: The Planning Framework, Height and Density..................................... 38

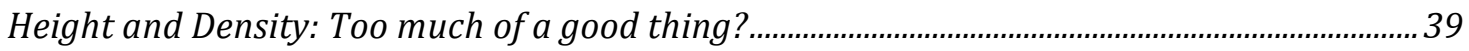

Infrastructure - The Current Context ....................................................................................... 41

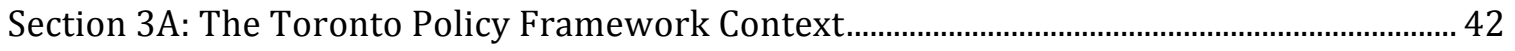

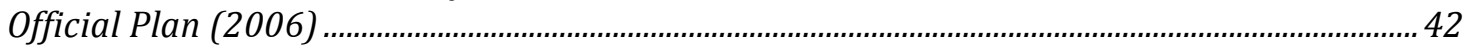

Legislative tools raised in the Official Plan - Managing Growth and Change............................45

Downtown Tall Buildings: Vision and Supplementary Design Guidelines (2012)..................... 48

Secondary Plans and Site and Area Specific Policies - North Downtown Yonge Site and Area

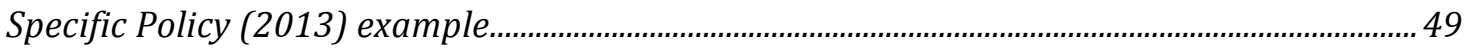

Toronto's Planning Framework - A Site-by-Site Approach .......................................................51

Section 3B: Alternatives to Site-by-Site Planning - Development Permits System .................. 51

Development Permits System: Reset TO Community Meeting Highlights...................................54

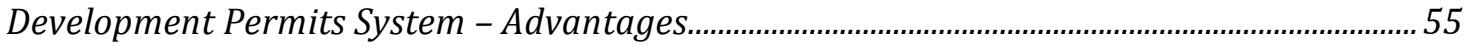

Development Permits System - A Shift in Instrumental Power ..................................................56

Development Permits System - Major Critiques........................................................................5

The Development Permits System and Quality of Life ..................................................................5

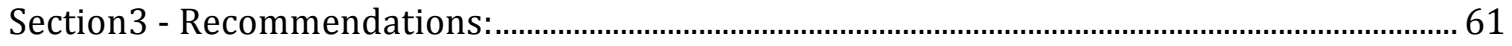


Conclusion ...............................................................................................64

Appendix 1: Public Realm Assessment Tool......................................................66 66

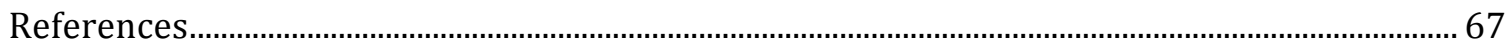

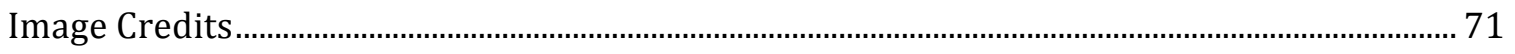




\section{Introduction}

In an age where many city centres struggle to attract innovation, kick start economies and retain talented residents, Downtown Toronto finds itself in the enviable position of having to manage a seemingly limitless stream of investment, growth and new prospective residents. This is a problem that all central cities would be eager to have: A rapidly swelling population, subsequent office development in key sectors, and a diverse and cosmopolitan range of entertainment and cultural amenities to match. However, as public investment and policy development always struggle to keep pace with internationally driven investment, a growing chorus of stakeholders are beginning to question whether the City of Toronto has the capacity to accommodate this growth while maintaining a high quality of life for its residents.

It is important to note that the robust economic climate and remarkable street-level vitality that Downtown currently enjoys are being driven by population growth (TD Economics, 2012). According to the 2011 Living in Downtown and the Centres Survey (City of Toronto, 2012) the vast majority (77.5\%) of new residents in the area reside in buildings 5 or more storeys, a figure that is likely to be considerably higher now. In order for high-density urban living to work for people and be considered a viable and sustainable alternative that endures development trends and market booms, the new residents of vertical communities must perceive themselves to be enjoying a high quality of life. If residents' needs are not being met, we risk a return to low-density suburban housing preferences and the costly landuse mistakes of the past.

\section{Purpose of Study}

The incredible scale and pace of development - unfolding along a relatively short period of time - sets the backdrop for this discussion. This paper focuses on Downtown Toronto, which has seen growth on a scale that demands attention. Between 2006 and 2011, Downtown areas like Concord CityPlace - which a decade ago was abandoned railway lands - saw a 434 per cent rise in those five years, according to Statistics Canada (Bascaramurty, 2012). I explore key elements around 
high quality of life for residents of vertical communities in the context of rapid growth, and discuss a range of ideas to sustain the desirability of living in urban centres from an urban planning perspective. Building on ideas from Short (2012) this discussion paper asks if and how tall, high-density residential developments might strengthen the character and dynamism of the Downtown.

Analysis presented here will focus on key issues around this growth by considering the impacts of height and density on quality of life from three lenses, including:

1. Priorities of people living in high-density residential developments with a focus on challenges relating to small living spaces.

2. The public realm, the importance of walkability, and ways to measure the performance of existing conditions from a people-centred perspective.

3. The ability of the planning framework to manage height and density and the potential of an alternative approach to improve quality of life outcomes.

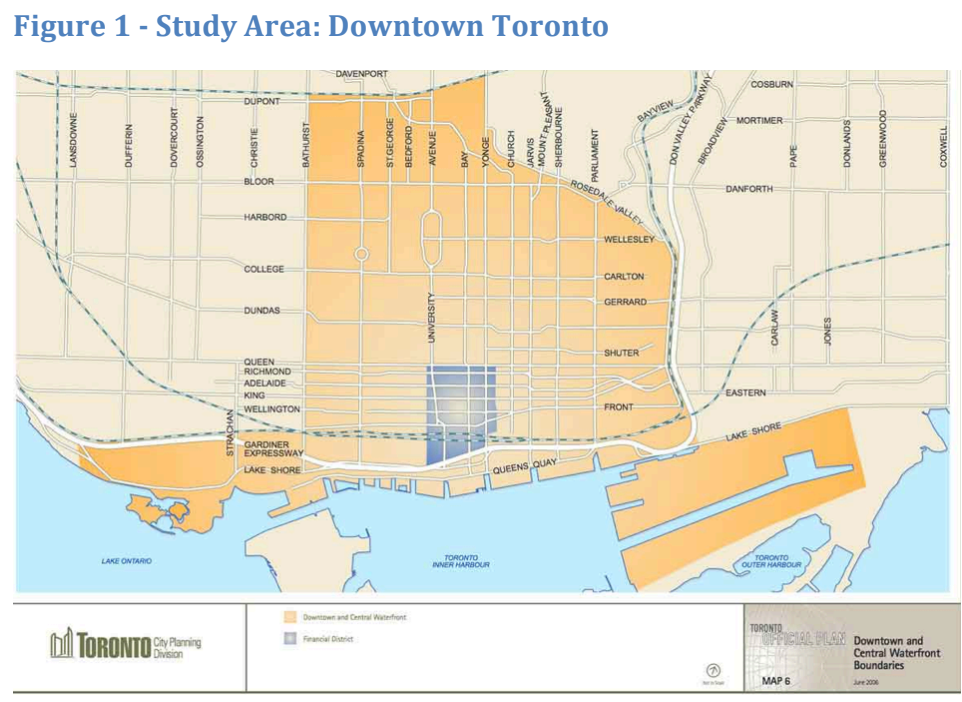

For central cities generally and Downtown Toronto especially, the costs of highdensity living falling out of favour with notoriously volatile housing markets would be grave. Given scale of high density development

Source: City of Toronto (2006)

and National Household Survey data showing that over three quarters of the Downtown population is living in buildings three storeys or higher, it becomes clear that satisfaction with this new lifestyle is not only important, but is in fact pivotal to the sustainability of Downtown Toronto. 


\section{Methodology}

Generally, the discussion presented here considers a wide range of topics on three different scales - life inside the building, life around the building and the broader planning framework. This approach was chosen as it allows for an understanding of height and density and quality of life from three distinctly different scales. The intent is to begin at the individual scale and 'zoom out' in each section. The wide range of topics strives for a breadth of discussion across these different scales.

\section{Conceptual Framework: Quality of Life}

One of the most important roles of urban planners is to be effective communicators. This means acknowledging that planning has had historical tendencies toward overly technocratic, process-oriented ways of knowing, and should instead strive to engage all communities in the discourse of how their cities and lives are affected (Fainstein, 2000; Innes, 1995). In the context of urban planning in Canada, facilitating accessible communication around complex issues is considered part of the planner's responsibility to the public interest (Canadian Institute of Planners Code of Practice, 2010, Section 1). As engaging increasingly diverse publics in planning processes becomes ever more important, planners are striving to use consistent and easily understood language that frames complicated issues in a way that is meaningful to the average person. It can be argued that the term 'quality of life' is an attempt at this.

This frame is particularly salient currently, as messaging coming from the City of Toronto has recently emphasized the term in its communications. 'Quality of life' is pervasive in language used by City Planning Division documents and media releases, but also appears frequently on the City of Toronto website, and is a featured subheading in The City of Toronto Strategic Actions 2013-2018 plan.

Chief Planner Jennifer Keesmaat recently citied quality of life impacts as a main consideration in the division's non-support of a high profile Frank Gehry designed mega-development in the King-Spadina area of the Downtown (Hume, 2013). This choice of words signals that the term carries meaning beyond semantics or branding. 
Despite its frequency of use by the City of Toronto, this term is never clearly defined. Recent literature suggests that consistently used language like 'quality of life' and 'livability' are employed according to what rationale is in vogue for planners at the time. Searle and Fillion (2011) emphasize the idea that language changes with circumstances. They point out that ways of framing the issue of residential intensification have shifted from fiscal responsibility in times of tight municipal budgets (e.g. higher density is cheaper to provide) toward quality of life benefits such as health and less car reliance (p.1429). On the other hand, quality of life is also used as a catch-all term to describe quantitative measures of city livability such as water, power, transit and a host of other infrastructure capacities. Such a quantitative approach is employed by the popular Mercer City Livability Index, The Martin Prospertity Institute's Livability Index and many others, all of which employ exhaustive and disparate sets of indicators to define quality of life (Okulicz-Kozaryn, 2013).

Given that quality of life is used as a framing device to tell a story about complex planning issues, a question arises: Is quality of life a set of quantitative metrics or is it purely a conceptual idea about how well different aspects of city perform for their residents? Literature on quality of life and the city suggests a balance: Shumi's (2013) discussion synthesizes existing literature to suggest that quality of life is: "Objective conditions together with subjective perceptions...[and is] generally agreed to be multidimensional having subjective and objective attributes" (p.6). It is this definition of quality of life that I will use in this discussion, bearing in mind that the use of the term is intended to tell a complex story in a manner that is easily understood. In sum, quality of life is a useful lens to consider challenges around density and its outcomes for citizens.

\section{Quality of Life: Focus Areas}

Quality of life should not be considered a definitive of scientific measure for the simple reason that selection of indicators can be arbitrary. However, in order to 
give meaning to the term, planners must rationalize what areas they choose to focus on and why they are important to people.

This work uses qualitative and quantitative data from the Living in the Downtown and the Centres Survey (City of Toronto, 2012), as well as the Condominium Consultation (SWERHUN, 2013) undertaken by the City of Toronto to support the 5-year Official Plan review. These datasets are used as a way to identify key issues important to quality of life as they give us a window as to what Downtown life means to its residents. The focus areas selected for the analysis are based on the highest priority issues and top-ranked responses. The primary advantage to the data employed here is that it captures the lived experiences of residents and their priorities (many of them qualitative), as opposed to expert and data-driven livability indices, bearing in mind that "after all, what matters is what we perceive, not what is out there"(Okulicz-Kozaryn, p.433-37). Addressing this aspect is important, considering the challenges of supporting the idea that living in vertical communities is (or can be) a viable choice that works for people.

Table 1 - Quality of Life Rationale for Sections 1 and 2

\begin{tabular}{|c|c|c|}
\hline Section & $\begin{array}{l}\text { Living in Downtown and the } \\
\text { Centres Survey Data }\end{array}$ & $\begin{array}{l}\text { Quality of Life } \\
\text { Implications to test }\end{array}$ \\
\hline $\begin{array}{l}\text { 1) Life inside the Building: } \\
\text { Residents and quality of } \\
\text { life }\end{array}$ & $\begin{array}{l}\text { Nearly half of respondents } \\
\text { indicated they intend to } \\
\text { move within the next } 5 \\
\text { years } \\
\text { Number one reason for } \\
\text { planning to move was to } \\
\text { seek a larger unit or one } \\
\text { with more rooms. }\end{array}$ & $\begin{array}{l}\text { Need for a better range } \\
\text { of unit sizes. } \\
\text { Increased need for } \\
\text { common spaces to } \\
\text { augment small } \\
\text { personal living spaces. }\end{array}$ \\
\hline $\begin{array}{l}\text { 2) Life Around the } \\
\text { Building: Surrounding } \\
\text { community and quality of } \\
\text { life }\end{array}$ & $\begin{array}{l}\text { Top } 2 \text { reasons for choosing } \\
\text { to live downtown (access } \\
\text { to transit and proximity to } \\
\text { work) closely related to } \\
\text { walking accessibility. } \\
\text { Downtown residents like } \\
\text { the fact that they live in an } \\
\text { area that offers an "active } \\
\text { urban lifestyle" with a } \\
\text { variety of amenities }\end{array}$ & $\begin{array}{l}\text { The public realm } \\
\text { (streets, parks and } \\
\text { open spaces) will play } \\
\text { an increasingly } \\
\text { important role in } \\
\text { accommodating } \\
\text { growth - especially in } \\
\text { terms of walkability. } \\
\text { New strategies are } \\
\text { required in order for }\end{array}$ \\
\hline
\end{tabular}


Table 1 briefly summarizes the basis for determining what key issues will be focused on. The data points to several issues of importance, but it must be emphasized that this represents a small subsection of issues around quality of life in the Downtown. Both of these sections are deliberately people-centred.

Table 2 - Quality of Life and Planning Frameworks

\begin{tabular}{lll}
\hline Section & $\begin{array}{l}\text { Existing Planning } \\
\text { Framework }\end{array}$ & $\begin{array}{l}\text { Proposed Alternative } \\
\text { Framework }\end{array}$ \\
\hline 3) The Planning & Toronto Official Plan (2006) & $\begin{array}{l}\text { Draft Official Plan Policies for } \\
\text { Implementing a Development }\end{array}$ \\
Framework, Height and & $\begin{array}{l}\text { Downtown Tall Buildings: Vision } \\
\text { and Supplementary Design } \\
\text { Guidelines (2012) }\end{array}$ & \\
& $\begin{array}{l}\text { North Downtown Yonge Site and } \\
\text { Area Specific Policy (2013) }\end{array}$ & \\
&
\end{tabular}

Table 2 is describes the policies considered in Section 3. This section takes a different approach, as it 'zooms out' to consider how height and density is regulated in current and proposed planning policy frameworks. The link to quality of life here is all-encompassing and is meant to explore how high-level policy can create the conditions for development that is tied to its capacity as well as that of the priorities of residents.

\section{Definitions}

\section{Tall Buildings:}

The Official Plan (2006) Policy 3.1.3 states that buildings whose height is greater than the width of the road allowance are considered tall buildings. This paper focuses on areas where building heights are many times greater than road allowances, but it is important to recognize that Downtown is home to many stable lower-scale neighourhoods where very little change is anticipated. 


\section{Density:}

The Provincial guiding document Places to Grow: A guide to the Growth plan for the Greater Golden Horseshoe (2006) defines density as people and jobs combined per hectare. While this is one of the most fulsome ways to define density, Statistics Canada often uses residential density as a measure, which it calculates as number of dwelling units per sq km. Similarly, this paper defines density as the number of dwelling units per hectare.

\section{Condominium:}

Often confused as a building typology, condominiums refer to a type of legal ownership tenure. Condominiums are a situation where a 'double' form of ownership, is created "where specific individual units are owned and registered in the name of buyers, while ownership over the residential common property is shared" (Rosen and Walks, 2013, p.161). Frequently referred to as 'condo' in this paper, the typology most frequently considered will be the physical design of a glass tower that has driven much in of the Downtown's growth in developments such as Cityplace.

\section{Context}

\section{Policy Overview}

All urban growth and transformation in Canada is shaped by provincial priorities, but in the case of the GTA, provincial policy aimed to limit sprawl has had dramatic impacts for urban planning. The Provincial Policy Statement sets out objectives that growth should be managed in order to promote efficient use of land through intensification and redevelopment of built-up areas (Policy 1.1.3.3). In directing growth to specified urban centres - including Downtown Toronto in its entirety the Growth Plan for the Greater Golden Horseshoe (2006) has helped to guide urban intensification on a massive scale for growth areas. The Growth Plan for the Greater Golden Horseshoe dictates that 40 percent of new development in single-tier municipalities must occur in already built-up areas by 2015, with Downtown 
Toronto compelled to meet density targets of 400 people by 2031. According to MPP Glen Murray's office, Downtown Toronto sat at 708 people and jobs per hectare in 2012 (Bencharif, 2012).

\section{Demand and Development}

It is important to note that while provincial policies shape urban growth, they are only part of the story. While provincial policy acts as a guide, consumer demand and

Figure 2 - Development Pipeline in King-Spadina area, Downtown Toronto

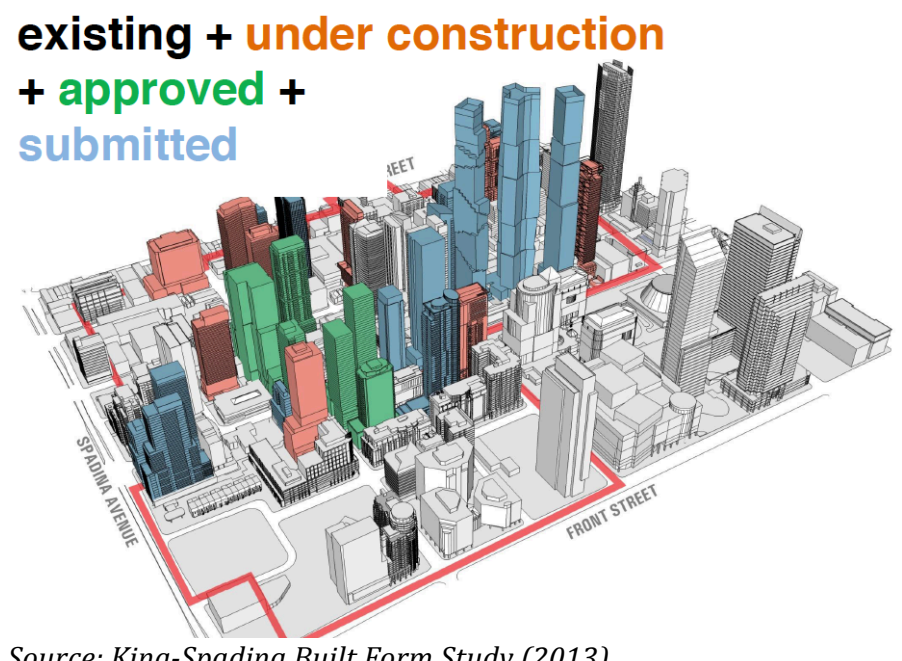

demographic shifts are the main drivers of an enduring trend toward higher density residential development in the Downtown and Growth Centres in the GTA. The market response to this new demand illustrates a clear break from traditional low-density

suburban housing preferences. In Downtown Toronto, single family housing construction fell by $9 \%$ between 2005 and 2010(Collins-Williams, 2013), while high-rise projects now represent the majority of new residential developments. In the period between 2006-2011, population growth in the Downtown surpassed that of the surrounding suburbs for the first time in decades (City of Toronto, 2012). Most remarkably, The GTA is expected to grow by $50 \%$ by 2031 , giving Toronto and its Downtown one of the fastest global population growth rates (Toronto Board of Trade, 2012).

This remarkable scenario is attributed to the 'condo boom' of the early $21^{\text {st }}$ century, which has been felt on a national scale, with the central cities of Toronto, Montreal and Vancouver seeing a 30\% increase in the share of condominiums to total housing development in the period from 1981 to 2006 (Statistics Canada, in Rosen and Walks, 2013, p.164). What makes Toronto a special case is that it has no North 
American analogue. Between 2007 and 2012 the City of Toronto's share of the Greater Toronto Area's total housing completions jumped from $28.2 \%$ to $40.4 \%$ (City of Toronto, 2013). The Downtown has been cited as having the highest rate of high-rise condo development on the continent (Perkins, 2014), with approvals three times higher than New York City and seven times more than Chicago (Francis, 2012).

Of course, the influx of new residents alone cannot explain the story of the resurgence of Downtown living. Concerns that global capital driven property speculation and 'assignments' (original buyers selling units before they are completed) are artificially inflating prices have been the subject of sustained media scrutiny, but have proven elusive to study given the lack of quantifiable data and an unwillingness on the part of the development community to share their information on the subject (Urbanation, 2012). While this discussion does address this issue, the emphasis will be on the tangible impacts current growth patterns hold for Downtown residents.

This resurgence of interest in city life can be framed as an intersection between shifting social geographies together with changing priorities toward the physical and spatial geographies of the city. Literature and available data increasingly suggest that we are seeing value shifts that prioritize a lifestyle that includes walking to work and daily necessities, convenient access to transit/less car reliance, and a comprehensive array of cultural and entertainment amenities (Rosen and Walks).

For proponents of residential intensification, this is strong ground. People willing to live, work and establish communities in dense urban areas represents demonstrated advantages to public health (people are walking more), sustainable land consumption, the environment and energy (less cars, less space to heat and light) and service provision (infrastructure needs can be supplied easier and less expensively) (in Gee, 2012 and Chakrabarti, 2013). 
However, order to meet the lifestyle priorities of these new residents, there is the underlying assumption that downtowns have the capacity to provide in terms of both community services (or soft infrastructure) hard infrastructure such as transit, roadways and hydro. As economic and cultural dynamism shifts back to central cities, municipalities and policymakers are faced with the challenge of laying the groundwork to meet the expectations of a skyrocketing population while making growth sustainable.

Downtown has been so successful, in fact, that the City itself recognizes that the pace of development is occurring on a scale that was not anticipated (Bascaramurty, 2012). There is a palpable anxiety around the magnitude of development as a result, as a growing body of media articles and residents groups begin to ask different angles of the question: How much density is too much?

\section{Context - Transit Framework}

The politically charged nature of the debate and the complexity of the transit issue make for an uneasy fit into a discussion such as this that touches on a breadth of issues. As such, the TTC requires a discussion of its own to adequately unpack and properly assess.

However, in terms of quality of life, it must be noted that transit is considered to be an issue of primary importance. Access to transit was the second most popular reason for residents locating Downtown, according to the Living in Downtown and the Centres Survey (2012). The apparent inability of any level of government and their agencies, boards and commissions to make headway on Downtown gridlock will most certainly create more urgency around the issue. A recent TTC report projects Downtown ridership to increase by over $50 \%$ by 2031 (236,000 trips in the morning peak, from 155,000 now) with employment projected to grow 28 per cent in the same timeframe (Kalinowski, 2012). The idea of a Downtown 'relief line' as a potential solution is nearly a century old, but is made more urgent by mounting 
crowd congestion issues along the Yonge subway line, and a newly redeveloped Union Station projected to reach capacity within a generation according to some (Ibid.). With the council approval to fund a subway extension to Scarborough, funding and political entanglements make transit relief for the Downtown seem distant.

Surface streetcar routes within the Downtown paint a similarly dire situation. With the TTC adding new streetcar routes along the Harbourfront without adding new cars to the fleet in 2000, a long overdue higher capacity streetcar fleet is slated to bolster key routes by late summer 2014. Apart form increased capacity of cars, there is no fleet plan to increase surface service levels on streetcar routes (Munro, 2014). As transit commentator Steve Munro notes, streetcar service has increased only 10\% between 1998 and 2014, indicative of a widening disconnect between infrastructure and growth rates (Ibid). 


\section{Section 1: Life Inside the Building - Residents and Quality of Life}

It is difficult for quantitative-focused livability indexes to properly capture what life is like for residents of a given residential development. Even subjective conceptions of life in tall buildings are coloured with sophisticated lifestyle marketing and the cosmopolitan images that are unlikely representations of the practical concerns and values of everyday people.

In order to draw out what matters to residents, we can look to the City of Toronto's Living in Downtown and the Centres Survey (2012), which indicates the following key findings around satisfaction, housing priorities and quality of life according to residents:

- $47 \%$ of Downtown residents plan to move in the next five years

- The top reason given for planning to move was to seek a larger unit with more rooms.

- $77.5 \%$ of Downtown residents live in buildings in 5+ storeys, over half of whom live in buildings $13+$ storeys

The first finding is very significant as a potential indicator of satisfaction with highdensity living. That almost half of respondents (47\%) indicated that they anticipated moving in the next 5 years signals that current living conditions are unsatisfactory in the short term. The reasons given for wanting to move is instructive to planners and policymakers:

Table 3 - Projected Mobility in Downtown Toronto

\begin{tabular}{llc}
\hline i) Top 3 Reasons for Moving in the Next 5 Years & & \\
\hline Reason & Rank & \% of Responses \\
& & $24 \%$ \\
Larger Unit/More rooms & 1 & $14 \%$ \\
Purchase next home & 2 & $10 \%$ \\
Affordability issues/Cheaper maintenance fees \& taxes & 3 & \\
\hline
\end{tabular}




\begin{tabular}{lll}
\hline ii) Anticipated Structure Type of Future Residence & & \\
\hline Condominium/Apartment & 1 & $47 \%$ \\
Detached or semi-detached home & 2 & $29 \%$ \\
Row/Townhouse & 3 & $10 \%$ \\
Other/Don't know & 4 & $14 \%$ \\
\hline
\end{tabular}

Source: Living in the Downtown and the Centres Survey, City of Toronto (2012)

Given these results, we can make a number of inferences. First, Downtown residents like where they live. Downtown was ranked 8.2 out of 10 on average for neighbourhood satisfaction (City of Toronto, 2013), and the vast majority of survey respondents want to stay in their current area. However the most common reason given for moving is a lack of space. Interestingly, as section ii of the above tells us, nearly $60 \%$ expect their next residence to be within a high-density condominium, apartment or townhouse.

This data presents a challenging scenario: almost half of respondents want to move because their unit is too small to suit their short term needs, yet they want to stay Downtown and they anticipate living in a similar high-density housing type as they do currently.

\section{Quality of Life Indicator: Small Unit Sizes}

As small unit sizes are the main reason for almost half of survey respondents wanting to move, it demonstrates that perceptions of small living spaces are a main determinant of the quality of life of residents. The following two sections focus on high-density condominium developments, as they represent disproportionately large shares of the housing stock in the Downtown.

Addressing the issue of smaller unit sizes comprehensively would require scope beyond that of this discussion. The following sections look to two pertinent planning issues directly related to the perceived lack of living space. These sections were selected for several reasons. First, they relate to recently released datasets that quantify the priorities of people living downtown, which is consistent with the methodological approach taken here - which is, that perceptions are what really 
matter in terms of quality of life. Second, the following two sections are recurring issues in the media and political circles and have a time-sensitive aspect that suggests a critical discussion around them is timely.

It is important to note that the following sections are pieces of a larger story - they are not intended to be comprehensive. It must be mentioned that market dynamics shaping development patterns downtown are a central determinant of evershrinking floor areas. As investment properties, smaller units are especially desirable as their carrying costs (condo fees and property taxes) are lower as they are calculated per square foot. To developers, units on the smaller side of the spectrum represent the 'sweet spot' that are easiest to sell in presale stages, thus increasing the likelihood of securing financing for the development (Perkins, 2014). This, combined with 'assignments' (flipping before units are completed) and questions around design and demographics, illustrates that a broad range of planning and market considerations are driving the trend toward smaller units.

\section{Section 1.A: Small Unit Sizes and Common Spaces}

The turn of the century has seen fundamental shifts in how people are choosing to live. Downtown Toronto has been on the vanguard of these shifts, with preferences for high-density urban life making remarkable gains over larger, lower density housing options on the urban periphery. Even within the housing typologies of high density living - often in tall buildings - the shape of dwellings within vertical communities is shifting.

Table 4 - Average GTA Unit Sizes

\begin{tabular}{lll}
\hline Year & Average Size & \% Change \\
\hline 2004 & 850 sq. ft & - \\
2013 & 822 sq. ft & 3.2 \\
2014 & 796 sq. ft & 3.1 \\
\hline
\end{tabular}

Source: The Globe and Mail (2014); Canadian Broadcasting Corporation (2012) 
Already small unit sizes throughout the GTA are shrinking especially fast in the most intensified areas. Over the last 10 years, the average unit size of new residential units in the Downtown has shrunk by 8 percent. It is also increasingly common for new developments to offer 'micro' units in the 390 sq. ft. range, a trend that some developers insist is not pushing the boundaries of livability (Perkins, 2014).

The results of the Living in the Downtown and the Centres Survey (2012) seem to contradict this claim, given that $47 \%$ of residents intend to move within the next 5 years, with the main reason for moving being to find a larger unit. In the context of this, the challenge facing planners is multifaceted. Can small living spaces in Downtown's high-density developments be augmented by strategies to provide common spaces outside of personal homes? Perhaps more importantly, will innovative approaches to common spaces offer sufficient quality of life benefits to convince current residents to stay in their current units?

\section{Common spaces as a solution to small living spaces}

A common line of thinking from a real estate and marketing perspective suggests that a cosmopolitan social and consumer life around buildings offsets small living spaces inside buildings. The suggestion that small units force people outside of their private spaces and therefore invigorate public life is matched by marketing strategies that portray the modern urban dweller as too social, work-oriented and/or wealthy to desire or require additional space (Langolis, 2012,

Zoning By-Law Chapter 15 Residential Apartment 15.10.40.50 Decks, Platforms and Amenities

(1) Amenity Space for an Apartment Building In the RA zone, an apartment building with 20 or more dwelling units must provide amenity space at a minimum rate of 4.0 square metres for each dwelling unit, of which:
(A) at least 2.0 metres for each dwelling unit is indoor amenity space;
(B) at least 40.0 square metres is outdoor amenity space in a location adjoining or directly accessible to the indoor amenity space; and
(C) no more than $25 \%$ of the outdoor component may be a green roof. p.108). Architects take a more fulsome approach, suggesting that the smaller unit sizes associated with high-density living ought to be harmoniously coordinated with open spaces and natural landscapes in order to work for their inhabitants (Gyarmati, 2008). 
The urban planning perspective adds to this by ensuring that indoor as well as outdoor common space ${ }^{1}$ for the exclusive use of residents is also present. The policy framework in Toronto has led planners representing the City and subsequent Ontario Municipal Board decisions to interpret indoor amenity spaces as way to compensate for smaller unit sizes in high-density residential buildings (Brant Park Inc. v. City of Toronto, 2013). This also may have been the intent of City of Toronto Zoning By-law 569-2013 (see right), which requires private indoor amenity space to provide recreation and socialization space for residents without placing undue burden on public amenities. The Official Plan also confirms the need for amenity spaces in more general terms.

Although required by the ZBL, the idea that amenity spaces are part of the solution to small units is not explicit in policy. This de facto position of the City was put to the test in the OMB decision Brant Park Inc. v City of Toronto. The developer made the case to the board that the proposed 11 storey, 243 unit residential development reduce the indoor amenity space from the $486 \mathrm{sq} \mathrm{m}$ required by the ZBL to $98 \mathrm{sq} \mathrm{m}$, stating that residents understand that relying more on surrounding outdoor activities and services was part of the "lifestyle expectation" (Ibid, p.4, s.14). In a significant decision, the board ruled in favour of the City, stating that parks, community facilities and surrounding outdoor amenities (bars and restaurants) are not an appropriate substitute for indoor amenity space (Ibid). Although it is not explicitly articulated in policy, it is clear that both the City and the OMB consider indoor amenity spaces to be important to the quality of life for those living in vertical communities.

While the literature on the importance of common spaces often does not refer to condo amenities specifically, they do fit under a body of work that considers 'third spaces'. A 'third place' is somewhere that one can relax and have the opportunity to

\footnotetext{
1 This refers to amenity spaces, which are typically associated with condominium residential developments. Outdoor amenities are privately owned and publically accessible, whereas indoor amenities are for exclusive use of residents. Indoor amenity spaces include: game rooms, gyms, party
} 
socialize in without judgement, used as a kind of retreat or counterpoint from the 'first' and 'second' places of home and work (Oldenburg and Brissett, 1982). While usually used in reference to the public realm, it is also recognized that there are many privately owned third spaces, which could include cafés, bookstores and condo amenity spaces (though these would only be accessible to building residents). The research on third spaces emphasizes the importance of these places for socialization and community interaction. Living environments lacking access to these third spaces are likely to produce lower quality of life "as a consequence of the increasing narrowness of people's spheres of involvement with others" (Ibid, p.282). Interestingly, almost all of the literature on third spaces focuses only on social and environmental elements contributing to sense of place, quality of experience and assigning personalized meaning to the experience (Laing and Royle, 2013). The literature does not explicitly state that third spaces play a functional role in terms of providing additional living space - this connection is implied and qualitative at best.

Getting back to the idea that quality of life is about the perceptions of people; we now turn to what residents think of amenity spaces as a solution to small units. At a recent City of Toronto public meeting that considered the impact of growth and change in the King-Spadina area of Downtown Toronto, a participant expressed that in-building amenities are important as third spaces away from offices and relatively small units (King-Spadina Built Form Study, November 25 $5^{\text {th }}, 2013$ ). This sentiment finds further ground in a City of Toronto initiated public consultation with Downtown condominium residents, where the majority of attendees agreed that amenity spaces were important to preserve as they were seen as additional usable spaces that represented one of the few ways to strengthen a sense of community inside the building (SWERHUN, 2013). Interestingly, 75.7\% of survey respondents from the same consultation indicated that there were sufficient social amenities like patios, rooftop spaces and common areas in their buildings (Ibid). 
Based on these consultation results, amenities are important both as an additional space and as a place for socializing. Most importantly, most residents consider them to be currently meeting their needs. This indicated satisfaction with amenities may be complicated by motivations of cost savings rather than use value and quality. This was clearly indicated in the Condo Consultation survey cited above, as residents saw amenities as important, but had serious reservations around their impacts on condo fees (Ibid).

Under the condo tenure model in Ontario, monthly condo fees are charged per square foot of the unit purchased by the individual, and then divided between reserve funds for capital expenses and operating costs (which would include maintenance costs for amenities). Simply put, the more extensive the amenity package, the higher the operating costs and therefore the higher the condo fee charged to the resident(s). As amenity spaces age, they tend to become more expensive to maintain, thus driving condo fees up. A Globe and Mail article points out that condo fees in aging buildings on Queens Quay can run \$700-800 per month for a unit of $1,000 \mathrm{sq} \mathrm{ft}$ (Chada, 2013). If, for instance, a major maintenance issue occurs, as was the case with the tar leak and subsequent pool closure of the TCHC owned St. James town pool in 2010 (Dempsey, 2010) condo owners will be faced with the choice between 'mothballing' amenities or to shoulder large scale increases in condo fees.

Given that residents want to keep costs down, but also value amenity spaces as important, we need to consider how they are being used.

Table 5 - Concerns Around Condo Amenity Costs - Anecdotal Evidence

Condominium Consultation Round 2 Online Survey Responses
"I have lived in a condo for over 20 years and never use the amenities. The fitness equipment in the building is
very popular with many residents. Eliminating amenity space would help to keep maintenance cost down."
"I like the convenience of having amenities directly in my building"
"Developers should be guided by the actual use of in-house amenities. Swimming pools, for example, do not seem
to be sufficiently used to justify the added maintenance costs. Party rooms and gyms are always busy."
"I usually see that the condo amenities aren't enough to support the residents of the condo"


Source: SWERHUN Condominium Consultation (2013)

In terms of quality, a sample of resident comments laid out in Table 5 echo the Condominium Consultation summary feedback and media coverage to suggest that while specific amenities are over-used (party rooms, rooftop patios, gyms) others go unused and should be eliminated to reduce costs (SWERHUN; Chada; Fleming 2012). This challenge is partly due condo buildings with high proportions of nonresident owners, who sign agreements that include amenity packages that will not affect them directly, and therefore less consideration is given to their practical use (Consultant_1).

The question facing planners and developers then becomes - how to provide a better quality of life through indoor amenity spaces that are desirable by residents while keeping costs down?

\section{Section 1.A: Innovative approaches to indoor common spaces}

In this section we set out to explore whether indoor common spaces could be used as part of a solution to address residents' concerns of small living spaces in highdensity residential units in Downtown Toronto. Through the discussion so far, together with recently released from the City of Toronto's Condominium Consultation, we have established the following:

- Condominium indoor amenity spaces are important to residents.

- While seen as important, there is a high concern over operating and maintenance costs in the form of condo fees.

- Popular amenities are over-used, while others are not well used and are seen as a financial burden.

- While common spaces have been linked to social and community benefits, it is unclear whether they are a sufficient solution to small living spaces.

Taking these points into account, the following section explores innovative ways forward and explores examples, strengths and weaknesses of each. 
Indoor amenity spaces are considered club goods in economic terms, meaning they are excludable services provided to those who buy in, and are non-rivalrous (Warner, 2011). However, considering that the well-used amenities are overburdened (e.g. relatively small gyms are busy and crowded; party rooms booked well in advance) the element of rivalry is most certainly an issue. Warner presents an interesting approach by suggesting we think beyond the club: "The challenge for planners is to think of what other roles government might play to promote a more sustainable and equitable role of clubs in an urban system" (Ibid. p.164). This certainly makes sense in terms of efficient resource provision. Given that the City is financially constrained to provide resources, it does not make sense for seven swimming pools to be provided privately within two city blocks (Consultant_1).

If Warner and the key informant are saying that there might be a role for government in resolving some of the challenges around private amenity provision, it is a useful lens in which to consider the findings of the City of Toronto Condominium Consultation. In designing the survey and shaping talking points for public meetings around this work, the City of Toronto Planning Division attempted an approach that looked beyond on-site amenity micro-issues and instead tested ideas to address the amenity provision problem on a broader scale.

A talking point/survey question designed with this broader approach in mind asked participants if they supported the idea that developers could reduce the amount of amenity space they provide (as currently required by the $\mathrm{ZBL}$ ) in individual buildings if they instead contributed toward the creation of a neighbourhood community facility open to the public as well as to condo residents (SWERHUN,
City of Toronto Staff Report - May 22, 2012

Alexandra Park Revitalization Plan

571 Dundas Street West, 21, 21a, 23, 23a, 91 Augusta Avenue, 73-75 Augusta Square \& 20 Vanauley Street -

Official Plan Amendment - Final Report.

The proposed Community Recreation Hub will replace the existing TCHC-owned community recreation centre and will include:

- Collective indoor amenity space for the exclusive use and management of TCHC tenants and Atkinson Housing Cooperative members as required by the Zoning By-law; and

- Additional indoor community space, which is open and accessible to members of the public.

(Emphasis author's own) 
p.31). Consultation participants generally supported this idea, suggesting that this 'neighbourhood community facility' should be provided in lieu of the less frequently used amenities. While still in the exploratory phase, the concept is to provide indoor amenity space that is flexible in design and programming, allowing for social, community and recreational programming.

The form this neighbourhood community facility would take could be modelled on the proposed community recreation hub detailed in the Alexandra Park Revitalization Plan (as suggested by Planner_1 and UrbanDesigner_1). The plan outlines a centrally located stand alone building containing both private and publically accessible indoor amenity space intended to serve a cluster of high and low rise residential buildings as well as the surrounding community. The hub will be owned, programmed and maintained by TCHC and the Atkinson Housing Cooperative members (Urban Strategies, 2013).

Although the management structure for a condo development would look different and would undoubtedly present logistical complications ${ }^{2}$, the Alexandra Park Revitalization model meets the expressed need of residents to retain some amenities as private, while also offering a host of other benefits. These include: a) Increasing the publicly accessible stock of amenities for the benefit of the all members of the public; and b) Potentially improving quality due to economies of scale; and c) Lowering condo fees by imposing user fees where appropriate on nonresidents for the public component of the indoor amenities. However, the logistics of providing such a facility on private land would require financial incentives of some form to be provided to the developer by the City, and would be administratively difficult if the space were shared by multiple landowner organizations.

\footnotetext{
2 The biggest barrier to this idea is that in a TCHC situation, land would be publically owned, whereas this would not be the case in a facility shared by any more than one developer. The notion that the public would have access such a facility worried some survey respondents, who raised issues with security. A key informant suggested that this latter issue might be overcome by using separate entrances for the public portion and the 'residents only' portion of the space (UrbanDesigner_1).
} 
Logistical stumbling blocks aside, this model could also hold additional benefits for building community, as these 'third spaces' would reach beyond individual buildings to a neighbourhood level. As current building-by-building indoor amenity spaces only offer space for interaction within a given building, a community recreation hub or neighbourhood community facility holds potential for increasing social cohesion across buildings in a vertical communities. This also has the potential to open up amenities and social interactions across a more diverse income range, as it features a publicly accessible component.

On the other end of the spectrum, an alternate, less ambitious Downtown Toronto example exists that has taken up the idea of pooled amenity spaces. The Harbour View Estates luxury condo development complex incorporates 4 tall buildings ( 5 and 10 Navy Wharf and 5 and 35 Mariner Terrace). Residents of all buildings share access to "Superclub" facilities and private courtyard with water features. The Superclub is a massive $30,000 \mathrm{sq} \mathrm{ft}$ indoor amenity space featuring the most luxurious facilities in the City (Dash Property Management, 2012). However, the Superclub takes advantage of economies of scale as it is shared by so many units even as the amenities offered are more extensive and of ostensibly higher quality, the condo fees are on the lower end of the spectrum for Downtown Toronto at 58 cents per sq. $\mathrm{ft}$ based on a sample unit listing in 35 Mariner Terrace. ${ }^{3}$ Although this approach does not contribute to publicly accessible amenities and is more limited in its potential for achieving social goals when compared to the Alexandra Park example, it provides a more practical solution and keeps condo fees down while providing a higher quality third space that extends beyond a single building.

A third example takes this idea further. In response to neighbourhood pressure, Lanterra Developments, along with councillor Wong-Tam proposed that parkland dedications owed by the developer from multiple developments spread throughout the Downtown be 'pooled' to create a higher quality greenspace on one site (11

\footnotetext{
${ }^{3}$ Calculated from a sample listing from One Percent Realty Website. Retrieved from: http://ab.onepercentrealty.com/listingdetails.cfm?lid=40054\&pfuse=realtordetails\&start=1
} 
Wellesley) in a parks-deficient area (LaRusic, 2013). Although this section does not look at outdoor amenity space (and recognizing that parkland dedication is outside the scope of this discussion), it is interesting to speculate how this 'pooling' could work to increase the quality of indoor amenities. If zoning requirements or Section 37 agreements for the provision of indoor amenity space could be pooled in a similar way (which would require an OPA), perhaps we could see amenities that serve residents living in small units better. This would present challenges ${ }^{4}$, but also could provide services that focus more on quality versus quantity, a guiding principle supported by many practitioners (UrbanDesigner_1).

\section{Challenges: Pooled Amenity Spaces}

As most of this section has considered solutions to small living spaces in the context of condos, it is useful to step back and consider the larger picture. It is important to recognize that condos are not simply a relatively new form of tenure and ownership. They also carry dramatic implications for physical design (see Toronto's Downtown skyline), social governance, security and social status. Rosen and Walks (2013) are helpful for the purposes of our discussion, as they attest that condos are "redefining traditional boundaries of public and private spaces"(p.161).

In their investigation of how condo-led growth is transforming Downtown Toronto, Rosen and Walks found empirical evidence (albeit with a small sample size) that the single biggest predictor for supporting 'privatization of public services' (no further explanation was given in the survey) was being a condo resident in Downtown Toronto (2013, p.168). This supports the idea that this form of tenure is 'remaking' downtowns on a social level, and may suggest that condo dwellers are more apt to support privatization of public life than other residents.

\footnotetext{
${ }^{4}$ Issues include some residents gaining more benefit by being closer, and others having to travel to use said amenities. A definition of reasonable distance and access would likely be contentious. It must be noted that the developments in the Lanterra proposal are described as being very close to each other.
} 
The Condominium Consultation draws out this theme the talking point/survey question mentioned earlier that asked participants if they supported the idea that developers could reduce the amount of amenity space they provide (as currently required by the ZBL) in individual buildings if they instead contributed toward the creation of a neighbourhood community facility 5 for public and condo resident use. While public meeting response seemed supportive, this idea was one of the least popular of all on the Condominium Consultation online survey, with only $35 \%$ of respondents indicating any level of support (SWERHUN). Issues raised included costs of management and maintenance, liability, safety and the perceived 'taking away' of the few amenities available to residents. Most of all, online comments were concerned that homeowners would be making double the contribution for community facilities by paying taxes as well as funding a community centre.

The survey results clearly demonstrate that Downtown condominium residents currently exhibit very low support for publically accessible amenity components, confirming to some degree Walks and Rosen's assertion that this group is more supportive of the privatization of urban life.

The model of shared yet exclusive (non-public) access to amenity sites outlined in the Harbour View Estates 'Superclub' example may still be an attractive option to residents, however. If more developments occurring in close proximities could pool their resources to create pooled amenities of better quality and somewhat broader potential for social interaction, it may have potential to improve quality of life outcomes regarding small living spaces.

\section{Common Spaces as a Solution to Small Living Spaces - Summary}

This section looked at the potential for indoor common spaces as a solution to address the problem of small living spaces. Resident feedback from the King-

\footnotetext{
5 This neighbourhood community facility is also referred to as a 'pooled amenity space'. Generally, this is understood to be a standalone or adjoined structure that provides indoor amenities for more than one building.
} 
Spadina Built Form Study and the Condominium Consultation Rounds $1 \& 2$ outlined several key priorities. First, indoor common spaces are important to quality of life for residents, but they were also viewed cautiously. Second, well-liked spaces like gyms and party rooms were frequently over-burdened and over used, while less used amenities were seen as increasing condo fees over time with ongoing maintenance and operating costs.

Suggestions around innovative approaches to a more collective approach to amenities generated a divisive response. While respondents were eager to access better quality amenities at lower cost, a majority opposed any solutions to pooled amenities that offered a public access component, citing concerns over management and the idea that they would be 'paying double' through condo fees and property taxes.

Based on these findings, the connection between amenities and quality of life appears to be tied more closely with social and recreational aspects rather than being a part of the solution for living space. However, this increasing social cohesion does have the potential to increase place attachment and quality of life aspects, as several empirical studies show that friendliness of neighbours and interactions with familiar faces rate very highly in terms of neighbourhood satisfaction (in Chapman and Lombard, 2002, p.774). Summary evidence from the Condominium Consultation also supports this claim, citing the importance of amenities to community building (SWERHUN). Aside from the social potential of amenity spaces, it is not clear whether they play a significant role in addressing concerns over small unit sizes.

\section{Small living spaces: Stakeholder Responses}

Stakeholders confirm these suspicions that innovative approaches to indoor amenities will not be enough to address concerns over small living spaces.

In terms of publically accessible pooled spaces, it was emphasized that while they would represent a more integrated approach to planning, they require a proactive 
design. In built out areas, it would be very onerous to coordinate shared spaces among different buildings through retrofits (Consultant_1, UrbanDesigner_1). Further, the management structure could become extremely complicated, which is likely to be seen by residents as a threat to quality of life outcomes (Consultant_1).

As for solutions to small living spaces, a key informant suggested that simple, finer grain solutions would be more effective. Providing for more adequate storage space that compensates for small unit sizes has a big impact on improving living space. Information sharing sessions on strategies and design tools for maximizing space may also have tangible impacts for better adjusting to life in limited spaces (Consultant_1). It was emphasized that a better understanding of the micro-level details of the challenges in living in small spaces (e.g. small closets, lack of storage spaces for cleaning supplies) could help to identify a number of smaller, quick fixes that could have a demonstrable cumulative impact on quality of life without involving undue cost and management complexity (Consultant_1). Based on considerable experience with condo related planning issues, informants felt that a discussion around what constitutes a minimum livable unit size is long overdue (Consultant_1, UrbanDesigner_1, Planner_1).

Perhaps the most instructive insight was that while usable common spaces inside the building together with a suite of amenities in the surrounding neighbourhood were instrumental for a high quality of life, they would not be enough to mitigate people wanting to move to a larger living space. If unit spaces are perceived as small - as they are in the Living in the Downtown and the Centres survey (2012) - a large segment of residents in high-density vertical neighbourhoods will want to move (Consultant_1; UrbanDesigner_1; Planner_1).

While small units do have their place, informants to this discussion stress that this high-rise condo typology is being produced disproportionately. As these units are geared to young professionals and empty-nesters, they are not necessarily compatible through age and family life-cycle continuums, as many contemporary 
designs are 'aspirational' lifestyle choices that often exclude many segments of society, such as urban households with children (Martel, 2014, p.30). This is in line with perspectives from Councillor Adam Vaughn and architect Andreas Duany, who lament that the lack of diversity in housing typologies threatens the longevity of Downtown neighbourhoods (Keenan, 2014).

Based on data and on the perspectives of key stakeholders, this investigation concedes that common spaces are not sufficient to provide enough additional living space to convince residents with concerns over physical housing size to stay. The bigger picture perspective suggests that a better mix of shapes, sizes and designs of high-density housing would provide a greater range of housing options that could better address spatial concerns and lead to a higher quality of life for residents.

\section{Section 1B: A range of housing as a solution to small living spaces}

Section 2.2.1, Policy 1 of the Official Plan (2006) states that it will accommodate development that supports a full range of housing options. Urbanist Andres Duany suggests the City is far from meeting this aspiration, claiming that one of Toronto's main issues was that its residential buildings are concentrated at extremes: They are either very large towers or they are house-sized. This opinion is shared by Willcocks (2011, p. 81) in her assessment of Official Plan policies encouraging a diversity of housing:

Chapter 3, Section 3.3, Building New Neighbourhoods, describes the general guidelines for planning new neighbourhoods, with policy stating that they will be "viable as communities" and have "a housing mix that contributes to the full range of housing" (p. 3-23). This last policy does not clearly specify that each neighbourhood should have a full range of housing, only that the city as a whole should; however, this goes against the general concept of a complete community - one where people of all ages and at all stages of life have access to jobs, services, and housing within the familiar neighbourhood.

While the City has been making strides and earning accolades in studying and promoting mid-rise development along avenues (City of Toronto, 2014), this approach is not being applied to the Downtown. While a better mix of housing typologies might be preferable, it is not always practical, given that land values preclude certain typologies from being practical or desirable. Further to this the 
intent of the OP can be interpreted to promote a range of housing in terms of unit sizes and price ranges more so than morphologies. As prices and unit sizes are affected by density in built out areas like the Downtown, it would seem that stronger policies are needed to ensure that the range of housing set out in the vision of the OP comes into being. ${ }^{6}$

The Official Plan (2006) specifies in 2.2.1 Downtown Policy 1.b that the city will accommodate development that provides a full range of housing, but does not further elaborate. Toronto's Tall Buildings Design Guidelines (2013) suggest a specific approach to tall residential buildings that holds potential to broaden the range of housing types. The Street Animation chapter 3.1.2 suggests the following:

b. On streets with an exclusively residential character, line the base building with graderelated residential units with usable front entrances and windows to living spaces facing the street.

The supporting text goes on to say that "townhouse" style podiums add to street-level animation in a number of ways (interaction, natural surveillance) and broaden the range of housing choices (p.40). These "townhouse podiums" (image 1) fit under the broader tower-base form typology outlined in the Downtown

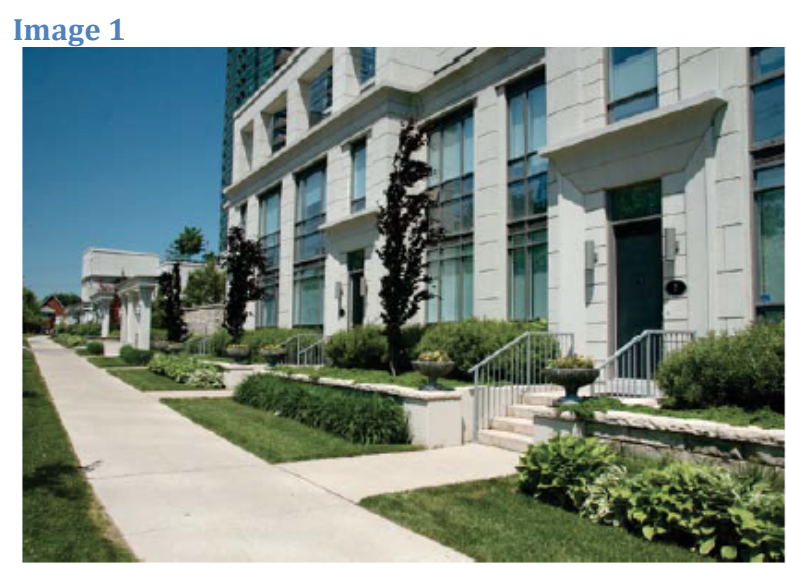
Tall Buildings: Vision and Supplementary Guidelines (2013). ${ }^{7}$

The townhouse podium design would broaden the range of housing options by providing for a greater flexibility of layouts, sizes and designs in the townhouse

\footnotetext{
${ }^{6}$ One key informant suggested this range of options is better achieved through incentives to the private market (Planner_1), although this would present challenges in keeping up with growth as it would diminish public resources.

7 Tower-Base Form typology is described as slender towers placed atop pedestrian-scaled podiums that define the street edge.
} 
podium, leaving units in the towers to more conventional high-rise designs. The City of Vancouver has been especially adept at implementing this model of townhouse style podiums (also known as "stacked townhouses"), which has contributed toward providing a fuller range of housing options (Wilcocks, 2011, 147).

While townhouse podium design addresses interior living space issues, it also holds broader potential due to its ground-oriented nature. This type of design, when concerted with sightlines conducive to monitoring and connections to outdoor common space, can have the capacity to make high-density housing more amenable for families with children. Vancouver's High Density Housing for Families with Children Guidelines (1992) and Seattle's FUN! Initiative both stress that in order for high-

Downtown Toronto Development - Lack of Options in Size and Layout

2012

- \# condos ready for occupancy: 6,005

- $63 \%$ are studios, one-bedrooms or one-bedrooms plus den

- $\quad$ Average size: $\mathbf{8 2 2}$ sq ft.

2014

- \# condos ready for occupancy: 9,090

- $\quad 67 \%$ are studios, one-bedrooms or one-bedrooms plus den

- Average size: $695 \mathrm{sq} \mathrm{ft}$.

density living to be appropriate for families with children, dwellings must be ground-floor oriented so children can easily access safe outdoor play areas (Wilcocks, p.160).

The issue of family-friendly housing in Downtown Toronto speaks to the quality of life issue around a lack of living space. Given that less than $10 \%$ of expected housing units expected for occupancy in the downtown in 2014 will have more than 2 bedrooms, there are few options for families in the range of housing options in Downtown Toronto (Yelaja). Significantly, empirical evidence compiled by Willcocks (2011, p.27) finds that:

Younger respondents living in high-density dwellings are more likely to move within five years than any other age group because of their position in the family life cycle. Howley (2009) suggests that urban planners and designers need to create residential areas that accommodate all stages of the family life cycle and provide a high level of stability and quality of life for residents of all ages 
This directly addresses challenges around the potential for mobility of residents in high-density dwellings. In order to address this, more family-friendly units must be added to the housing stock. ${ }^{8} \mathrm{~A}$ proposed Official Plan Amendment was raised in 2010 at the behest of councillor Adam Vaughn, recommending that any new developments in the Downtown of 100 or more units include at least $10 \%$ three bedroom units or a combination three bedrooms and units that can be combined to make a larger unit through 'knock out' panels. While commentators like Willcocks (2011) take the position that that this is the way forward to expand the range of housing options, this could be made more meaningful/functional by combining this approach with children's need for easy access to ground-oriented outdoor play areas, as raised in Vancouver's High Density Housing for Families with Children Guidelines. As ground-oriented units comprise a relatively small subsection of the housing stock, promoting family units in the townhouse podiums together with larger units on the upper floors (catering to groups of students, persons working from home, etc.) would contribute to a range of units in the most meaningful way.

The townhouse-podium form has several noteworthy precedents in Downtown Toronto. The Local at Ft.York features a 7-storey townhouse-style podium with active frontages and a 13-storey tower. The townhouse offers a number of larger, family friendly units that are billed as 2.5 bedroom units in the 900-1400 sq ft range (ONNI, 2014). Stand-alone stacked townhouse options without towers in lowerscale neighbourhoods are another way to broaden options while increasing density, as many provide larger two bedroom plus den configurations and unique floorplan layouts (Hanes, 2013). Stacked townhouses, whether as a part of a podium with a tower, or stand-alone, are part of a solution to address the gap between the extremes of Toronto's 'very tall or very small' built-form.

\footnotetext{
${ }^{8}$ It has also been noted that these larger units are desirable as rental units for students looking to cut costs through group accommodation as well as professionals who work from home and require office space (SWERHUN, p.18).
} 


\section{Section 1: Recommendations}

The first part of this section sought to explore the potential of indoor amenity spaces as a solution to small living spaces in the Downtown. Investigation into the issue has identified that innovative approaches to amenities are not likely to be enough to lower residential mobility rates in vertical communities with high proportions of small units. New approaches to amenities do, however, hold potential for increasing quality of life in other areas such from social (community building) and economic (lower condo fees and better quality amenities) perspectives. Going forward, recommendations include:

1. To support and explore pooled amenities where appropriate, looking to the 'Superclub' example at Mariner Terrace. These solutions would likely be exclusive to condo residents, due to low levels of support and high complexity of publically accessible pooled amenity spaces.

2. Combine community contributions from development, as seen at 11Wellesley with opportunities to combine parkland dedications should be further explored to provide higher quality, more efficiently produced amenities.

3. Support short term 'quick wins'. These could include identifying specific concerns around small living spaces and formulating smaller scale solutions through space saving design workshops and promoting better storage.

Based on feedback form key informants, the second section found that a key part of a strategy to address concerns with small unit sizes was to promote a broader range of housing options in keeping with the intent of the OP. Recommendations for highdensity, tall building residential development in the Downtown include:

1. Use site and area-specific plans with a stronger policy framework to provide a broader range of housing. Build on existing approaches such as the Mimico-by-the Lake Secondary Plan, which requires 5\% units to be three bedrooms (Planner_1). A more fulsome approach would require that 5-7\% of three bedroom family friendly units be provided in ground-related townhouse podiums; together with an additional 5-7\% of larger units - not necessarily three bedroom - required elsewhere in the building. This recognizes that demand for larger units comes from a variety of demographics.

2. Implement stronger planning criteria around the design, orientation and layout of housing - such as those in the Development Permits System 
(addressed in Section 3) - would force architects, designers and developers to be more innovative in providing larger units and family-friendly housing in cost-effective ways.

3. Implement frameworks promoting a range of housing in a timely way. As Willcocks (2011) points out, development along the waterfront and other key brownfield sites is occurring at a rapid pace. If the City is not quick enough in its implementation of stronger policies, the costs of this missed opportunity will be dire in terms of social diversity and high residential mobility rates.

Taken together, the provision of a range of housing options is the key challenge in addressing quality of life issues around smaller living spaces. However, urban life is about a full suite of elements that must be in place for people to feel that their neighbourhood works (UrbanDesigner_1). The next section considers a key element this suite of elements - the public realm around the building and how it relates to quality of life for Downtown residents. 


\section{Section 2: Life Around the Building - The Public Realm and Quality of Life}

Given the urgency around challenges of small living spaces that accompany recent development patterns in high-density living discussed in the previous section, this section will consider how outdoor spaces relate to quality of life in Downtown Toronto. Discussion here refers to the public realm, where 'life between buildings unfolds'. This domain is loosely understood as streets, alleys, entryways, parks, open spaces and bollards (Gehl \& Svarre, 2013). As studying the public realm entails many complex components, this section brief discussion focuses on an assessment tool that is specifically designed to give a data-rich rationale for improving the public realm and by extension, the quality of Downtown residents.

\section{Quality of Life Indicator: The Importance of Walking}

The Living in the Downtown and the Centres Survey (2012) finds that the top three reasons for living downtown are directly related to walkability.

Table 6 - Top 3 Reasons for Living Downtown

\begin{tabular}{ll}
\hline Reason for Choosing to Live Downtown & Rank and \% of Overall Response \\
\hline Close to work & $1(21 \%)$ \\
Access to public transit & $2(14 \%)$ \\
Access to shops/store/market & $3(7.1 \%)$ \\
\hline Source: Living in the Downtown and the Centres Survey, City of Toronto (2012)
\end{tabular}

Source: Living in the Downtown and the Centres Survey, City of Toronto (2012)

Taken together, walkability is a key component of $42.1 \%$ of respondents' choice preferences for living Downtown. Mode choice for work trips for single occupancy vehicles or carpools accounts for just $16 \%$ of trips according to survey respondents. As all three of the reasons given in Table 6 therefore rely on walking, it could be argued that walkability is a vital component of quality of life.

\section{Section 2A: Where we walk and quality of life}

Barbie Greenbie's insights into how we see our streets and sidewalks are a good starting point to thinking about these aspects of the street. Greenbie's analysis concluded that streets and sidewalks are often seen strictly as conduits - although they are public spaces because they are built and funded by public agencies, they are 
considered as such only in a categorical sense (1981). As a key informant and expert in the area suggested, the public is slowly coming around to consciously recognizing the importance of streets and sidewalks to the public realm (UrbanDesigner_1).

Unfortunately, this awareness is less about an appreciation for sense of place and more about a tangible sense that sidewalks are overburdened. The discussion around the amount of density Downtown has extended beyond transit concerns in the media recently, with academics, public consultation messaging and soundbites from the Chief Planner acknowledging that people are "falling off of sidewalks" (Keenan, 2014). However, as a key informant points out, this attention to sidewalks also presents opportunities to leverage public concern to create innovative solutions for sidewalks that are places as well as conduits (UrbanDesigner_1).

Sidewalks and streets are especially important in the context of constraints around the provision of greenspace. As parkland per capita is lowest in older, built up areas, and the availability and price of Downtown land is recognized as a major barrier, the City recommends "rethinking" existing conceptions of how green and open spaces are provided (City of Toronto Parks Plan 2013-2017). Part of this approach considers how streets could play a similar role that parks do in targeted areas. Proposals like the Entertainment District BIA's John Street Corridor envisions sidewalk widening, streetscape improvements and a more programmed sidewalk experience where one can linger and enjoy the public realm (see Image 2, p.34). Examples such as this are what my key informant refers to in terms of opportunities for leveraging public attention to provide a case for new approaches for the sidewalks and streets of the public realm. 

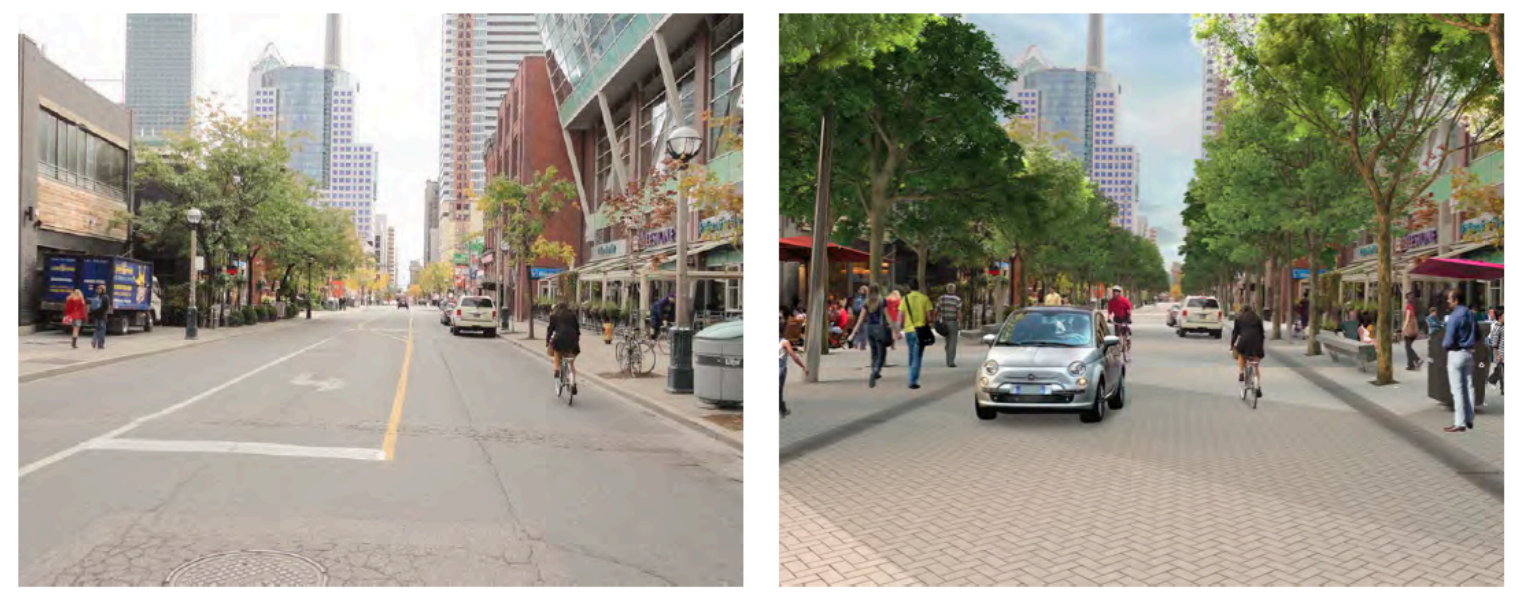

However, the intent of this discussion is not to focus primarily on design considerations, but rather to assess how the public realm can provide a high quality of life from the broader perspective of walkability. A better understanding of the public realm is required to make informed decisions about what type of streetscape improvements make the most sense and where they should occur. What is most interesting about this topic is that while so many area plans, studies and reports focus on the elements of the physical environment, relatively little is known about how people actually use the public realm (Gehl and Svarre, 2013). We have design solutions, as in the John Street example, and we have a sense that sidewalks cannot handle pedestrian flow, but what is missing is a cohesive understanding of the qualitative and quantitative story of how people interact with the public realm.

Research by Gilliard (2012) looking at Downtown Toronto is instructive on this point:

The City of Toronto should initiate a public life survey of the downtown to establish a baseline of data about how people use downtown public spaces. This data can provide part of the foundation for identifying Toronto's strengths and opportunities. It will also give public space advocates in the community and the civic bureaucracy the 'language' to make convincing arguments with numeracy-minded critics (43). 
Work that is currently underway as a part of a studio team project ${ }^{9}$ responds to this call. Based primarily on the approaches to studying public life set out by Jan Gehl, the next section discusses how to fit the missing piece of people into making a case for public realm improvement.

\section{Putting People First - A Public Realm Assessment Tool}

At the heart of this discussion is Jan Gehl's early critique of modernist planning. Claiming that the comprehensive, large-scale plans of the mid $20^{\text {th }}$ century had indulged the artistic visions of physical design at the expense of ignoring people. A sense of how and why people behaved the way they did in public space was lost or ignored. Gehl's antidote to this problem was to develop new tools to investigate the underlying reasons of what works and what doesn't (Gehl \& Svarre, p.60). His method of using direct observation to discern how people use a space tells a story about how it can be improved by a building a rationale and a direction for future planning interventions (p.3-4). ${ }^{10} \mathrm{~A}$ major advantage to this methodology is that it uses a quantitative base of data to match qualitative observations.

The tool our studio team has developed and piloted for the City of Toronto attempts to tie Gehl's methodology of a people-focussed approach together with an assessment of the existing conditions of the built form. ${ }^{11}$ The intent is to draw out a dialogue around the quality of the public realm. For a better understanding of how to interpret this tool in detail, please refer to Appendix 1.

\section{The Public Realm Assessment Tool and Quality of Life}

The public realm assessment tool (Public Realm Studio Group, 2014) gives users a simple and easily executed method of collecting data. This can be easily applied to open spaces, corridors and transit nodes. The following is an example of how the

\footnotetext{
${ }^{9}$ This project is to be delivered to clients at the City of Toronto, and was undertaken as a part of a group. Please see References section for the list of co-authors.

10 Direct observation (in the field) uses simple and accessible means of data collection to count, map, trace, and keep detailed journals of how people interact with public space (Gehl \& Svarre).

11 The assessment tool is divided into 3 focus areas: People (observing movement, activities and patterns), Place (an inventory of existing conditions) and Context (a larger scale look at connectivity, destinations and landmarks).
} 
data might be used to identify where planning interventions can improve the experience of walking - and therefore quality of life for Downtown residents:

1. Volume of Use - Counting pedestrians over a given time period and measuring this against environmental factors such as sidewalk width, pedestrian scale building enclosure, sun and shadow. This will give a sense of the existing capacity to support pedestrians in study areas.

2. Transit Stop Performance - Mapping size of crowds waiting at TTC stops and comparing against accessibility features (gripping, curb cuts), sidewalk widths, TTC shelter conditions will give insight as to how to better direct clustering of people in order to avoid right-of-way blockages and increase safety.

3. Measuring Illegal Crossings - Mapping locations and frequency of J-walking compared with block size, building widths and crossing infrastructure. This will give a sense of areas in need of improved pedestrian prioritization to improve safety and ease of movement.

4. Role of Privately Owned Public Spaces - Mapping and assessing how pedestrians might use these spaces - as thoroughfares (mid-block connections), as places to stay and linger, or not using them at all- will give a better understanding as to their role and performance in the public realm and how they might be designed and treated in future development.

These are only a few examples of the potential of the public realm assessment tool (Appendix 1) to better understand walkability and public realm performance. This tool is a powerful resource for planners seeking to understand the human element of Downtown public life, while attaching a numbers-based rationale that increases its potential to leverage investment in the public realm.

Given the concerns raised in Section 1 around small living spaces, the importance of the public realm as a third space amplifies its importance for quality of life outcomes in the Downtown - for better or for worse. As Gehl and Svarre attest, this represents an accessible way to understand the connection between space, its uses, and quality of life for people (p.70). As the top three reasons for living Downtown depend so heavily on the public realm and walkability in particular, resources of this kind are timely.

\section{Section 2 - Recommendation}

The sole recommendation of this section is to prioritize a people-centred approach to making a case for public realm improvements, to be integrated into background 
studies and neighbourhood profiles undertaken by the City Planning Division. The public realm assessment tool is a superior option and methodology for doing this, as it is cheaply conducted and makes for a compelling 'story' as it combines qualitative impressions with quantitative data 


\section{Section 3: The Planning Framework, Height and Density}

"We have reached this exciting and terrifying tipping point where we are starting to question whether it could be there is something called too much density...There are some areas of the city where we are seeing too much density - hyperdensity - and there are other areas of the city where we are seeing no growth at all."

(Toronto Chief Planner Jennifer Keesmaat in Gee, 2013)

The pace of growth that Downtown Toronto is currently experiencing is a contentious and divisive issue. Since the OP took effect in 2006, 82\% of development has been directed to Downtown and the centres, with the Downtown absorbing $41 \%$ residential proposals and 39\% of non-residential GFA in the city (City of Toronto, 2013). Such concentrated development at such a massive scale has seen a splintering among urbanists and residents. While many stakeholders agree that controlling growth and investment is a 'good problem to have', tensions arise as to what this surge in population and development will mean for the Downtown.

This section therefore considers the planning policy framework, its ability to manage growth and change, and the implications for the quality of life of residents.

\section{Height and Density: Too much of a good thing?}

As illustrated in the quote at the beginning of the chapter, Toronto's Chief Planner is one of many that believe the Downtown is hitting a 'tipping point' of the amount of density that an area is able to sustain. The Growth Plan for the Golden Horseshoe sets the density target for Downtown at 400 people and jobs per hectare. According to the Minister of Transportation's office, in 2012, Downtown Toronto

Growth and Change in Downtown Toronto

\section{$82 \%$}

of development has been directed to Downtown and the Centres since 2006

\section{0,300}

residential units; and

\subsection{7 million sq $\mathrm{m}$}

of non-residential GFA are proposed in the Downtown between January 2008 and December 2012.

Source: City of Toronto

How Does the City Grow? (2013) was sitting at 708 persons and jobs per hectare (Encharif, 2012). A chorus of journalists and academics warn that the influx of population and resource consumption will affect community services, parks and open spaces, sidewalks and streets in a way that will negatively impact quality of life for current and future residents. John Lorinc raises the point that Toronto does not link its approvals 
process to infrastructure carrying capacity, as projects are approved first on a siteby-site basis without being tied to the comprehensive suite of required infrastructure investments needed to serve new investments (2013).

Some commentators call for planners to recognize that density in itself is not a goal - it is a metric. Richard Florida and Edward McMahon contend that while density is essential for the viability of cities, it has tendencies to build up and over the human scale (driven by height precedents) and instead breeds isolating environments and "vertical sprawl" (Florida, 2012). In Downtown Toronto, there is some concern with large-scale developments encroaching on traditionally low or mid-rise neighbourhoods (Lorinc, 2012). Marohn warns that planners (and developers) treat high-density zoning as a "blunt instrument" that oversimplifies the relationship between density and good quality, context-based planning outcomes (2013). As a key informant attests, density is only a component of a suite of elements (mix of housing, public realm, community services and facilities, parks and open spaces) that contribute to a high quality of life (UrbanDesigner_1).

Others argue that very high densities part of the solution, not the problem. Unlike Chief Planner Jennifer Keesmaat, Chakrabarti sees hyper-density (defined as 30 housing units per acre - modest by Toronto standards) as a desirable and integral ingredient for successful cities. He dismisses the claim that high-rise, hyper-dense neighbourhoods in Toronto will turn out to be 'urban ghettos' and instead counters that tall, dense development facilitates successful mixed-use modern office development in ways that low-rise development cannot (2013, p.132). Further to this point, the Globe and Mail cites that $92 \%$ of office development in the GTA in the second quarter of 2013 occurred in Downtown Toronto. The article goes on to suggest that in light of job market gains and better proximity to work, infrastructure needs to keep up with the growth, as opposed to pursuing actions that stunt future growth in order for infrastructure to catch up (Gee). 
As divisive as height and density can be, both sides of the debate seem to agree that the planning tools and framework in Downtown Toronto are inadequate to manage growth in a concerted way. Summarizing his reflections on the unresponsive and out-dated nature of zoning, Chakrabarti identifies common ground in his suggestion that "good planning should be guided by desired objectives rather than prescribed physical outcomes" and advocates for a more flexible and performance based approach (p.145). How can this be done? As Michael Short (2012) asked - Is there a way to incorporate tall buildings and a range of other highdensity forms in such a way that improves the communities around them?

\section{Infrastructure - The Current Context}

Before we consider how the current planning framework speaks to height and density, it is helpful to establish a baseline of where Downtown stands in terms of its ability to support future growth. The following table is not intended to be definitive or exhaustive, but rather to give a sense of where Downtown stands currently.

Table 7 - Hard Infrastructure Capacity Highlights

\begin{tabular}{|c|c|c|}
\hline Infrastructure Type & Capacity Challenges & Notes \\
\hline Emergency Rooms & $\begin{array}{l}\text { St. Michaels total capacity } 45,000 \text { visits/yr. } \\
\text { Currently operating at } 70,000 \text { visits } / y \text {. }\end{array}$ & $\begin{array}{l}\text { Recent years have } \\
\text { shown visits to } \\
\text { increase by } 5-10 \% \\
\text { annually }\end{array}$ \\
\hline Transit & $\begin{array}{l}\text { Yonge and Bloor station at capacity; Yonge } \\
\text { subway line near capacity; } \\
509 \text { and } 510 \text { streetcars (Queen's Quay) ridership } \\
\text { up } 50 \% \text { from } 2004 \text {. }\end{array}$ & $\begin{array}{l}\text { TTC projects a } 50 \% \\
\text { ridership increase } \\
\text { in the Downtown by } \\
2031 \text {. }\end{array}$ \\
\hline Hydro & $\begin{array}{l}4 \text { of } 5 \text { Downtown power stations are operating } \\
\text { between } 86-92 \% \text { of capacity. }\end{array}$ & $\begin{array}{l}\text { This is considered } \\
\text { to be "unusually } \\
\text { high" }\end{array}$ \\
\hline $\begin{array}{l}\text { Greenspace } \\
\text { Parkland }\end{array}$ & $\begin{array}{l}\text { Most of Downtown areas feature } 0.79 \text { hectares } \\
\text { of parkland per } 1000 \text { people. }\end{array}$ & $\begin{array}{l}\text { Other areas near the } \\
\text { Downtown offer 3-4 } \\
\text { Ha per person. }\end{array}$ \\
\hline
\end{tabular}

Table 8 - Downtown Toronto Community Services and Facilities Capacity Highlights

\begin{tabular}{ll}
\hline Type of Service & Capacity Challenges \\
\hline Child Cares & $\begin{array}{l}\mathbf{6 2 \%} \text { of agencies reported being at or near operating capacity } \\
\text { most with significant waiting lists }\end{array}$ \\
\hline
\end{tabular}


Although programming capacity exists, there is a pressing need for more physical programming space (especially in aging facilities with less flexible spaces)

Human Services

(e.g. health, employment, training, shelters,

settlement services)

Libraries $\mathbf{5 8 \%}$ of agencies do not have existing capacity to take on new users or clients.

$\mathbf{8 0 \%}$ of programs will not have the space or resources to accommodate new users over the next 5 years.

Source: City of Toronto, Strategic Initiatives, Policy and Analysis (2013)

The above information should be taken together with the idea that the GTA is expected to grow by $50 \%$ its population by 2031(Toronto Board of Trade, 2012). Much of this growth will be targeted to growth areas such as the Downtown. As infrastructure capacity stands at what it does in a financially constrained environment, this raises questions of what growth will mean for the quality of life of residents. The next section considers how the current policy framework manages this challenge.

\section{Section 3A: The Toronto Policy Framework Context}

In theory, planning frameworks guide and direct the scale of growth in such a way that it is ostensibly tied to the capacity of infrastructure, taking into account environmental and design considerations. The following is an overview of policies pertaining to the scale of growth in terms of height and density. It also traces an evolution of policy thinking as the City attempts to keep pace with growth and change.

\section{Official Plan (2006)}

The Official Plan, last consolidated in 2010, is a document intended to provide guidance to how the City grows, but takes careful steps to avoid being overly prescriptive in its policy framework. This open, normative approach to crafting the OP was likely a reaction to the rigid, technocratic practice of past generations of planning that resisted the transitory nature of cities. As a CMHC report implies, overly prescriptive approaches to master planning and zoning can hold back natural processes of growth and change as neighbourhoods and uses must be allowed to continually responding to complex local and global conditions (1997). The King- 
Spadina area in Downtown Toronto is a key example - until its land use was updated through a series of secondary plans, the planning framework did not allow the area to move beyond its historical industrial-only function, thus severely constraining its ability to react to dynamic new opportunities (Ibid.). Bearing in mind that the intent of the OP is to allow for flexibility and change over time, we will examine key policies related to height and density contained within.

Section 2.2.1, Policy 4a relates to the scale of development, by specifying that intensification should occur in the mixed-use areas (outlined in red in Fig. 1) and the regeneration areas of the Downtown, with "sensitive infill" to occur in the Downtown Neighbourhoods and Downtown Apartment Neighbourhoods designations.

Figure 3 - Downtown OP Land Use Map
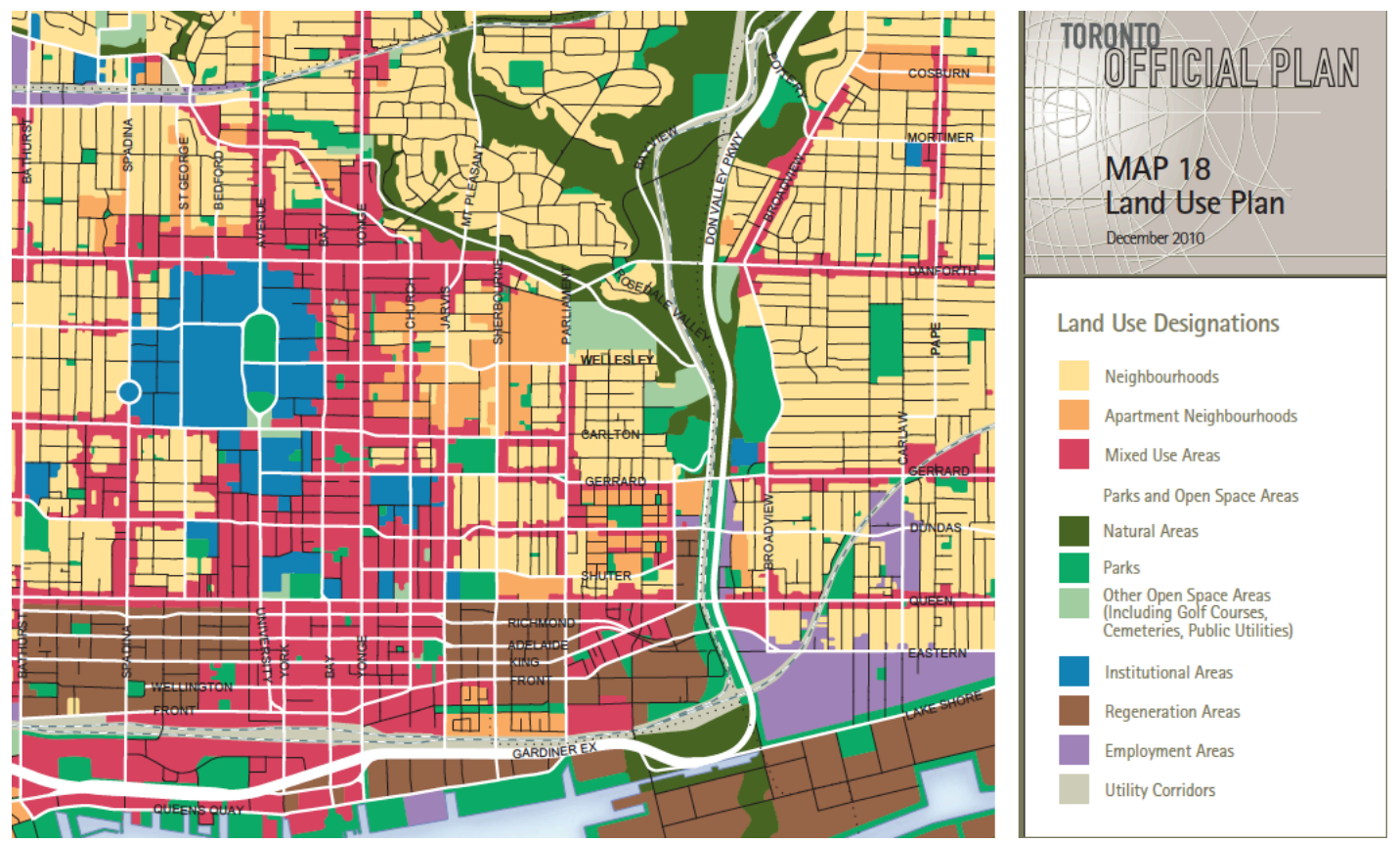

Land Use Plan

Land Use Designations

Neighbourhoods

Apartment Neighbourhoods

Mixed Use Areas

Parks and Open Space Areas

Natural Areas

Parks

Other Open Space Areas (Including Golf Courses,

Institutional Areas

Regeneration Areas

Employment Areas

Utility Corridors

Source: City of Toronto Official Plan (2006)

The red mixed-use and brown regeneration areas are where the majority of growth will be directed in the Downtown, which will be made to support residential, commercial, institutional and open space. Chapter 4.5 Mixed Use Areas Policy 2 
raises the importance of transitioning building heights from areas of differing character and intensity in qualitative terms. It is important to note that this chapter refers to the Downtown in a relatively homogenous way, outlining only that the Downtown will accommodate the highest buildings at the greatest intensity.

Direction in regards to height and density is set out Chapter 3 in the descriptive text (meaning non-policy items) in the OP. These items in Section 3.1.2 under Built Form, specify that height and density should follow limits set out in Secondary Plans and Site Specific Plans (to be discussed) and where none exist, developments should look to the zoning bylaw for a benchmark to assess height and density. Under the same section, a descriptive section (again, non-policy) sets out in very general terms the need for adjacent areas of differing height to 'transition' into each other, using loosely defined angular planes, massing orientation, and stepped heights.

Interestingly, Section 3.1.3 Built Form-Tall Buildings, does not suggest a finer grain of guidance in terms of height and density. Descriptive text recognizes that tall buildings are not appropriate in all areas, and are most suited to Downtown and the Centres within the mixed-use and regeneration areas, which, as we have seen comprises most of the Downtown. Further urban design guidelines are suggested pertaining to wind, shadow, pedestrian scale and street enclosure, but none are bound by quantitative measures.

Section 3.2.2. Community Services and Facilities provides a process for 'soft infrastructure', recommending in Policy 5 that "areas experiencing major growth and change will be informed through the preparation of a community services strategy". In this case, major change in an area - of which tall buildings are a driving force in the context of the Downtown - triggers a process. Table 5 is a part of this process, which requires the city to initiate:

- A neighbourhood demographic profile

- An inventory of existing services

- Analysis of service gaps

- Identification of priorities 
- Recommendations for service enhancements and strategies

- Identification of funding strategies

Policy 6 goes on to require this process be undertaken in any residential or mixeduse development over 5 hectares. Taken together, we have a planning policy mechanism that is triggered by the scale of development, with the intention that services must be assessed and a plan developed in order to accommodate new development. This triggering mechanism is similar to the parkland dedication outlined in Parks and Open Spaces 3.2.3 Policy 5, which specifies that developments over a scale threshold (dedications required per 300 units, dependent on the size of the site) must contribute land or cash-in-lieu.

\section{Legislative tools raised in the Official Plan - Managing Growth and Change}

Given that developments of significant scale trigger processes for community services and facilities as well as formula-based processes for parkland dedication, we look to what triggers the OP lays out for hard infrastructure capacity provision. On the surface, it would seem that no trigger exists for hard infrastructure. Chapter 5 - Managing Growth and Change, can partially explain this.

While not triggered by developments of significant scale exclusively, the Development Charges By-law (laid out by the Development Charges Act) requires all new developments to pay one-time charges to meet growth-related capital infrastructure requirements (transit, water, roads and upgrades). The intent is that growth should pay for growth (Slack, 2002). However, a consultants' report to the City found that development charges are covering well under $70 \%$ of the infrastructure costs required to keep pace with growth in the Downtown (Moloney, 2012). Ideally, development charges in Toronto are designed to respond to growth via a city-wide bylaw review that occurs every 5 years or sooner. But, in order to respond to growth related infrastructure pressure in high-growth areas, development charges would have to be changed on a city-wide basis. This proves to be a politically challenging situation, as it would be difficult to make the case for across the board increases to meet the needs of geographical minority of high- 
growth areas. The use of development charge by-law reviews to respond to growth related need is also frustrated by the fact that any development charge increase tends to pass a portion of the burden to the public via increased housing prices (Amborski, 2011). Although it is important to keep development charges up to date to reflect rising costs, their agency to keep up with growth is constrained.

Another way that the OP Chapter 5 recommends to manage growth is through use of Section 37 of the Planning Act, which allows for a range of community benefits to be provided by the developer in exchange for additional height and density above that permitted in the Zoning By-law. While this approach of going beyond as-of-right zoning regulations does trigger a process, it is important to note that community benefits can comprise a broad range of potential contributions, including, but in no way limited to capital infrastructure (Section 5.1.1. Policy 6). These benefits are currently negotiated by councillors, city staff and developers, adding further complexity to the process and reducing the likelihood that contributions flow to where they are most needed as opposed to what is politically opportunistic. Although S.37 does trigger a process, it is not shaped in the comprehensive way that a community services and facilities study is, which lessens its potential from a policy standpoint. 
Figure 4 - Section 37 Density for Benefit Agreements

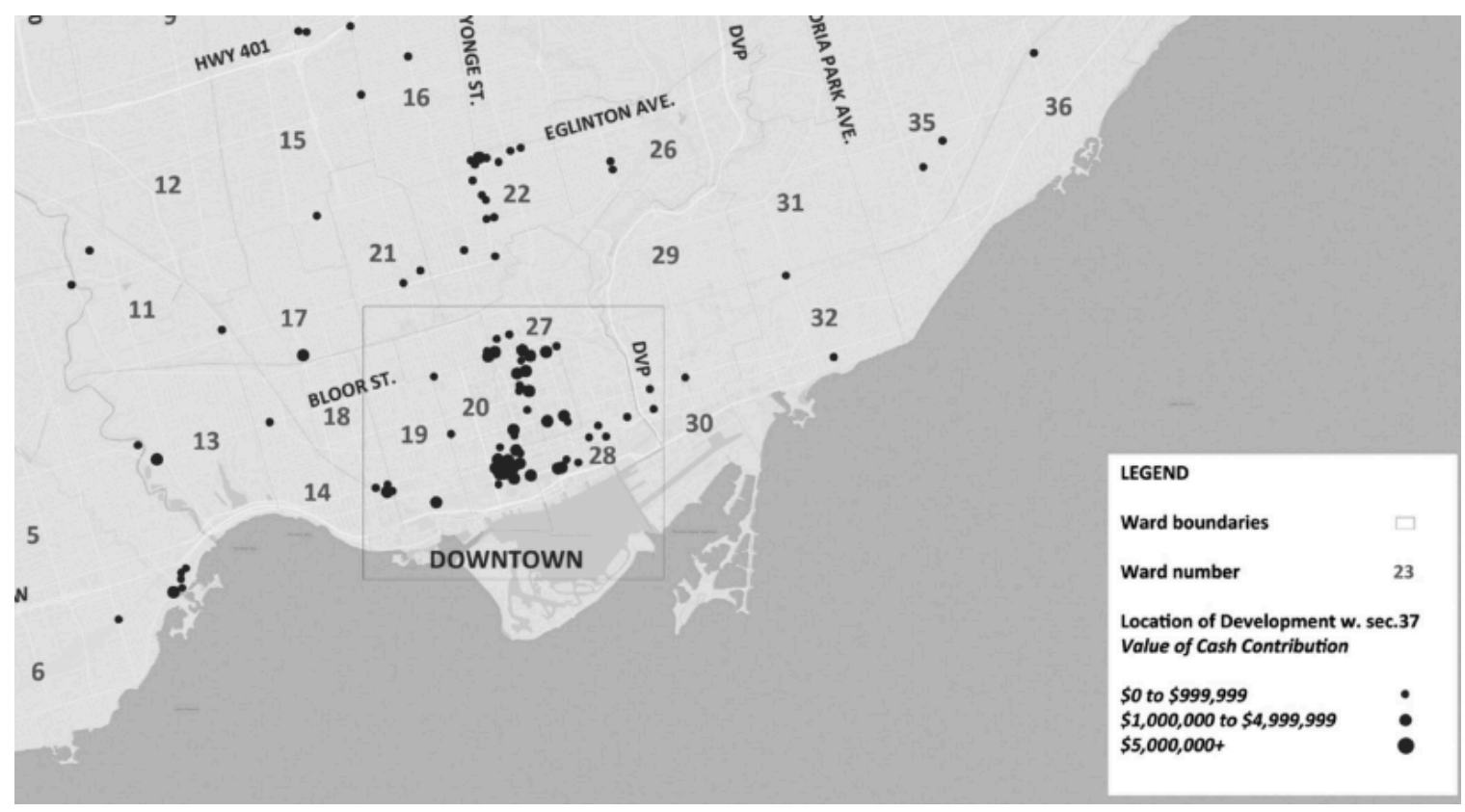

Source: Institute on Municipal Finance and Governance (2013)

Further, as a recent critique of Section 37 aptly points out (see Fig.2), most of these increases in density are occurring in wards experiencing the most growth-related pressure - Downtown wards 20, 27 and 28. The report goes on to say that the benefits provided are scattershot, as no one type of benefit accounts for more than $50 \%$ of the benefits in any ward (IMFG, 2013, p.5). From this, it is evident that Section 37 does not function as a trigger to keep up with or manage growth, as it is applied to a broad range of politically determined benefits - many with a preference for "desirable visual amenities" - that are not bound to core growth related need (ibid).

Overall, the OP provides sparse guidance in quantitative terms for developments of significant height and density. Although it specifies where growth is to occur (in the mixed use and regeneration areas), there are no metrics given or specific conversation around how much density is too much. Specific benchmarks are only suggested in the context of the Zoning By-law, which is frequently overridden in favour of Section 37 agreements. Furthermore, areas designated for growth (again, the mixed use and regeneration areas) cover most of the Downtown are as such, 
incredibly broad. This does not represent a fine enough grain of policy guidance to reflect the incredible variation of building typologies and magnitudes of density within the mixed-use areas. ${ }^{12}$ As scrutiny builds on this point, the City has responded by commissioning a consultants' report intended to address the need for greater specificity in the mixed-use land designations, which is discussed in the next section.

\section{Downtown Tall Buildings: Vision and Supplementary Design Guidelines (2012)}

In the introduction to this set of guidelines, the City of Toronto recognizes that rapid growth is testing the limits of the planning framework.

While the City's Official Plan has provided direction on the intensity and nature of this growth outside the Downtown and in areas of the Downtown subject to Secondary Plans, Official Plan policies have not provided a vision and a framework within which to address the specific issue of appropriate locations for the redeployment of height within these other areas of the Downtown (p. 1-2).

The guidelines set out an evaluation tool that suggests the conditions for compatibility with the surrounding context. Its main features are to suggest subcategories for the Downtown mixed-use areas, which are called High Streets and Secondary High Streets. Within these areas, the guidelines then go on to suggest 'height ranges' appropriate to each area, which include:

- A $137 \mathrm{~m}$ (45 storey) to unlimited height, outlined in the Financial District;

- 107-182M (35-60 storeys) in King-Spadina and other small parcels;

- 92-152 M (30-50 storeys) on a section west of Yonge and North of Haggerman St.

- 77-137M (25-45 storeys) along most of University ave; and

- Several other lower ranges for parcels of Church, Dundas and other streets.

The height ranges represent a significant addition on the policies of the $\mathrm{OP}$, as they set out quantifiable measures for what is appropriate in terms of height and builtform typology. The document also uses stronger language than the OP for heritage and impacts to parks and open space. Notably, emphasis is on design and

\footnotetext{
12 Although the OP does have a 5-year review process (earlier if necessary) to assess how its implementation tools are functioning, this review process must be comprehensive, making the review costly. Given the pace of growth and change in the Downtown, it can be argued that the OP review process is not agile enough to respond to emerging issues in a timely and cost-effective way.
} 
environmental impacts and includes no discussion around the capacity to accommodate growth.

It is equally important to note that this policy tool is intended as a guideline, and is careful not to stifle architectural or design innovation. As it is a set of guidelines, this document does not statutory weight behind it. While the height ranges are not binding, they attempt to provide "a finer grain of detail to more effectively guide the review and approval of Downtown tall building applications" (p.5).

Secondary Plans and Site and Area Specific Policies - North Downtown Yonge Site and Area Specific Policy (2013) example

While Downtown is host to seven secondary plans and many site and area specific

Table 9 - North Yonge Site and Area Specific Policy Height Areas (2013)

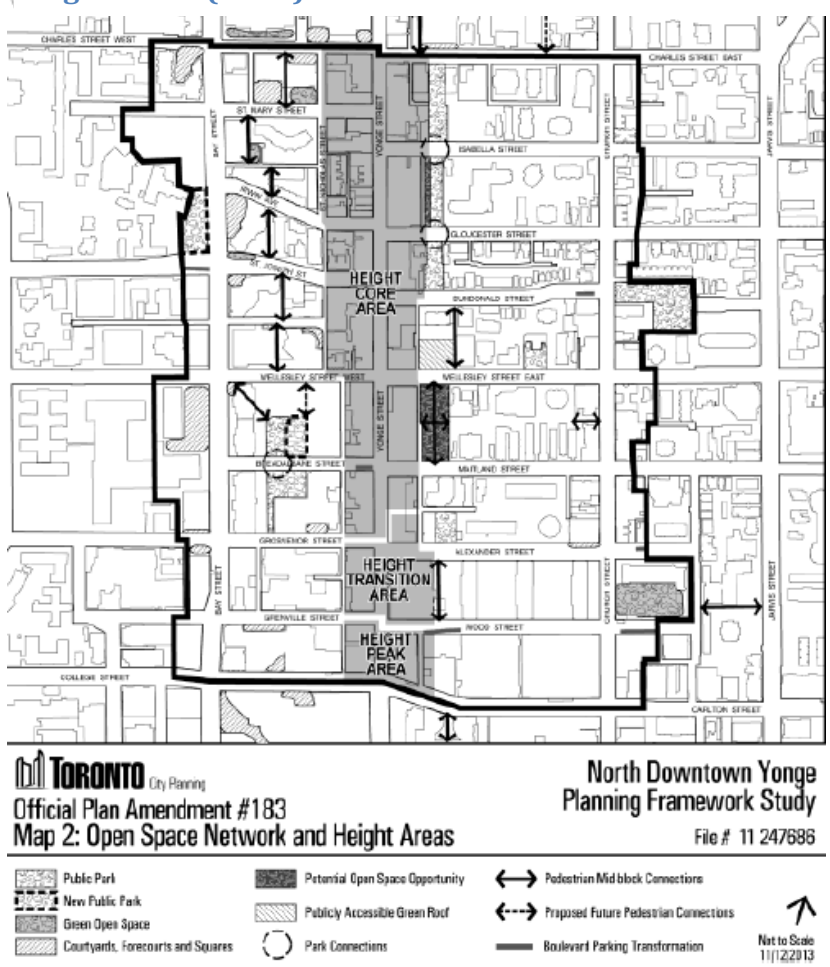
plans, the recent North Downtown Yonge Site and Area Specific Policy (2013) exemplifies the evolving approach of the City of Toronto to regulating height and density. This plan pertains to a "special character area" meaning one of architectural and historical significance. In this case, Yonge St. is considered historically to be Toronto's iconic main street.

As the policy relates to a special character area (and several subareas), it is much more prescriptive

in its scope than other general policies, recognizing the particular challenges posed by growth to existing lower-scale built form. Very large scale residential development occurring along key transit nodes (as directed in the OP) is beginning 
to move further into the fabric of the neighbourhood, prompting a more rigid set of policies than seen elsewhere in the Downtown, including:

- Core Height Area: In the range of 8M or 4 storeys (with a consistent 4 storey wall along Yonge) (Policy 5.3.1). Additional height will only be considered if no part of the proposal falls into a 45 degree angular plane and meets detailed heritage-sensitive criteria (Policy 5.3.9)

The Height Transition Area: In the range of 170M or 45 storeys (Policy 5.3.8)

- The Height Peak Area: in the range of 190M or 55 storeys (Policy 5.8)

- Tall buildings are "generally not appropriate" but will be given consideration in context so long as the tower portion of the proposal adheres to a minimum setback of 10 or 20 metres from the street - depending on the heritage aspects in the area (Policy 5.3.6)

- Includes detailed aspects of shadow impacts, height transition into surrounding lower-scale neighbourhoods and sensitivity to heritage.

It is interesting to note that the height transition area stipulates height in the maximum range brackets set out by the Downtown Tall Buildings guidelines. This follows good planning principles in terms of encouraging the greatest intensity around transit nodes (e.g. College Subway station), but 'transition' is quite dramatic from recommended 4 storeys in the core height area to 45 storeys in the peak area. It must be noted that the surrounding area is very much built out, which likely informed this transition recommendation.

Overall, this approach gives planners, developers and the public a much more specific sense of a finer grain of what built form to expect in the area. Even for a special character area, it leaves room for design innovation for taller buildings, so long as they adhere to more strict design guidelines around transition, angular plane and respect to heritage buildings and landscapes. In terms of height, this plan does increase the planning guidance from guidelines (such as Downtown Tall Buildings) up being enshrined in policy. Still, there is no policy 'trigger' that sets off infrastructure assessments. Tellingly, density is not mentioned in the policy in the pointing to the intent of the policy as having a focus on character, heritage and environmental impacts. Why then, not include density and its relationship to capacity in these guiding documents? 


\section{Toronto's Planning Framework - A Site-by-Site Approach}

In the absence of a deliberately prescriptive planning framework, planning in the Downtown must therefore rely heavily on subjective interpretations of general guidance laid out in the OP. At a Downtown public meeting, stakeholders suggested that general qualitative guidance from the OP does not give planners, citizens and neighbourhood organizations enough 'ammo' to provide a solid rationale at the OMB (King-Spadina Built-form Study, 2013). The only quantitative bounds on planning in Toronto are laid out in a zoning by-law that is routinely dismissed as out of date at the OMB (Blackett, 2010) and secondary plans that also do not reflect the reality of current development.

From a theoretical standpoint, Toronto's Site-by-Site approach is reactionary. Staff have come to expect that applications will seek to build above as-of-right, which places the City on the defensive (Planner_1). To many residents, this makes planning seem arbitrary, with the results of development approvals bearing little resemblance to the perceived rules laid in the ZBL (Reid, 2014). Most importantly, this approach represents an incrementalist view of planning, working through each individual application in hopes of doing the best that can be done given development pressures and the planning tools available (Forrester, 1984). This lack of policy guidance to put the intentions of the OP into practice have resulted in a 'spot zoning' approach, where city building is considered on the basis of individual

applications as opposed to a vision, a local context and an informed idea of cumulative impacts on quality of life.

\section{Section 3B: Alternatives to Site-by-Site Planning - Development Permits System}

In January, 2007 The government of Ontario set out a regulation in the Planning Act that allowed municipalities to make use of the Development Permit System (DPS), an alternative planning regulatory mechanism that Chief Planner Jennifer Keesmaat would later call a "fundamental shift" (Pill, 2014). Interestingly, in the first four years of its introduction, only three municipalities in the province took up the DPS. Then, in early December, 2013, the City of Toronto introduced a Official Plan 
Amendment with the intention of implementing the system. The timing of this in December, coupled with a lack of public consultation before the OPA was proposed to the Planning and Growth Management Committee, raised the ire of resident groups (Ibid).

The DPS is a proposed as a vision-based, neighbourhood approach to planning that will streamline the development process by front-ending flexible planning requirements on an area-by-area basis (Ibid). In other words, neighbourhoods will be consulted to shape a comprehensive plan under a single By-law for their area if they so choose (DPS is optional - in absence of an DPS area plan, current in-force planning rules apply as they do now), and any development applications afterward must adhere to the DPS area plan. In exchange for this more prescriptive approach, a streamlined approvals process will be offered, combining minor variance, zoning site plan and Section 37-style agreements into a single application, thus reducing the approvals process from the current 120-180 days to a proposed 45 days (City of Toronto, Nov.6, 2013).

The logic behind the DPS is that it outlines an area-based planning approach that considers planning on the scale of neighbourhoods, while it provides more certainty of outcome and considers planning in a broader, more cumulative way. In sum, the DPS is designed to address the shortcomings of site-by-site 'spot zoning' discussed earlier, as applications are considered in the context of an area, not as a stand-alone application. Central to this approach is the ideas that it allows for a more predictable and comprehensive way to plan for infrastructure, as the full build out for the area is established (flexibly) when the DPS area plan comes into force. A City Staff Report describes it as a cross between a secondary plan and a zoning Bylaw (Ibid).

Branded Reset TO, by the City Planning Division, the process works like this:

1. Stakeholders (councillors, City staff, members of the public, development community) frontend the consultation through meetings where an area-based plan is shaped. The process 
begins with a background study, which could include an assessment of existing and needed facilities and infrastructure. Next, a detailed land-use vision is formed, which would also measure the capacity for growth against hard and soft infrastructure capacity. Design details, heritage and character stipulations may also be included as they are in any areaspecific plans.

2. Once approved, the area-based plan would translate into a set of development standards and criteria that would work similar to a zoning bylaw (which would be repealed in any DPS area plan). A key difference is that height limits and other standards would be expressed in ranges. All zoning, minor variance and site plan would be consolidated into single area based by-law, which in turn would require a single development application (and faster approvals)

3. Development applications must meet the standards and criteria set out in the DPS area bylaw to receive a permit. While Reset TO materials indicate a 45-day review period, staff and community feedback suggest this timeframe is overly optimistic given the complexity of proposals of significant height and density.

4. Only the applicant (developer) has appeal rights on approval to the OMB. The rationale here is that community priorities are expressed up-front in the development of the DPS area plan, and therefore do not require an appeal mechanism. Third parties (councillors, resident groups, civil society) would not have rights to appeal. However, A key feature of the DPS is that appeals would apply to the entire area by-law (not the site), while would trigger a review process of the area by-law including new background studies, revised standards and criteria, and community consultations processes.

5. Under the DPS by-law, OMB decisions are limited to the same powers that council holds, meaning that the OMB cannot approve developments above by-law height regulations.

6. Community benefits similar to Section 37 would be built in to height ranges, requiring their provision within the existing as-of-right height standards set out in the by-law. Applications for the higher allowable height range would provide benefits, whereas for lower allowable ranges they may not be required. These benefits would be required to achieve a "proportional relationship between the quantity or monetary value of the facilities and the height or density that may be approved", using a formula-based approach that does not exist in current S.37 agreements. Benefits would also be prioritized up-front in background studies described in step 1.

7. The DPS would be reviewed over an unspecified timeframe - originally set as 5 years, but is currently being reconsidered by staff.

(City of Toronto, Staff Report, November 6, 2013, p. 4-10; Reset TO Community Meeting, March 22, 2014; inserted commentary author's own.) 
The overarching idea here is to create a system with a more consistent and coordinated approach to planning that considers development applications in the context of an area and its needs and existing capacity.

\section{Development Permits System: Reset TO Community Meeting Highlights.}

The March 22, 2014 Reset T0 meeting saw city staff lead an information session and

field questions. Community feedback and discussion with planners raised the following general issues around DPS implementation:

- How DPS areas will be defined and what types of areas they are best suited for has yet to be decided. Some personal suggestions from staff included employing DPS in high growth areas, but there is currently no consensus on this.

- The question of whether height limits in the development standards would be decided by precedent or by neighbourhood priority was a common concern that planners did not have an answer for.

- Given the significant resources needed for the process, staff estimated that only 2-3 DPS area by-laws per year could be implemented.

- Debate around cost issues of the DPS process were raised - although it was argued that more up front costs required by the DPS would cut costs overall as compared to the current system of meetings on every application

- Community members had enduring questions around removal of appeal rights and concerns around the additional powers given to planners under the DPS

Overall, the response at the meeting changed as more information came to light. Many representatives of residents' associations seemed to shift from confrontational tones to cautious optimism. Initially concerned around issues of removal of appeal rights, many participants seemed to express support for the DPS by the end of the meeting as it became clear that the OMB could not approve anything above height limits. On this point, reception from unofficial representatives of the development community were mixed. Although there was clear support for the expedited and simplified approvals process laid out in the DPS $^{13}$, it was suggested the idea would be unpopular with the general public due to

\footnotetext{
13 The Building Industry and Development Association hosted a panel discussion on the DPS in March 2014, which included supporters Chief Planner Jennifer Keesmaat and councillor Adam Vaughn. Although the BILD website is not expressly positive on the issue, the hosting of the event and press release language indicates support so far (BILD, 2014).
} 
the removal of appeal rights. Again, there was a tangible lack of trust in the expanded powers of planning staff laid out in a DPS.

Architects and design professionals present also indicated support. This positive feedback flowed from the assurance that design review panels and building performance standards could be included as requirements in the development criteria for DPS by-laws.

An overarching challenge seemed to revolve around logistics. As questions from the public rightly pointed out the slow process of initiating and updating secondary plans, they feared DPS implementation would not be fast enough to address growth challenges in the present. City staff suggested that it was feasible to implement 2-3 DPS area by-laws on an annual basis, which was a source of frustration for many.

\section{Development Permits System - Advantages}

The potential advantages to this are multitude for quality of life of residents. First, in an ideal playing out of a DPS, stakeholders have the advantage of taking the long view of building design, environmental impacts, area massing, and land-use, allowing people to effectively shape their neighbourhood in a proactive as opposed to reactive way. As the staff report points out, this helps eliminate the 'surprise' element of growth, as an DPS area plan would allow stakeholders to visualize, prioritize and express priorities for the neighbourhood as a whole, thus eliminating fatigue (and reducing cost) of holding consultations for every new development (p.4).

Second, this process eliminates the need to deal with outdated zoning by-laws and improves on the existing processes to provide community benefits. Any applications seeking to build beyond as-of-right would require a comprehensive review process including consultations (see step 4 above), which to City staff represents a much more onerous and rigorous test than the current Section 37 does (Reset TO Community Meeting). In this, the DPS sets out a 'hard cap' on height and density, 
representing shifts toward more stringent and clear expectations of what constitutes appropriate development.

Further to this, the current system provides community benefits on an ad-hoc basis (via Section 37 negotiations) on approved projects that exceed a zoning framework that does not reflect realistic expectations of development in the Downtown. Evidence suggests that negotiated Section 37 benefits rarely provide hard infrastructure needed to support density (IMFG, p.6). In contrast, the DPS identifies and prioritizes appropriate benefits beforehand, based on needs identified in a background study. This has potential for infrastructure to be clearly coordinated with growth in facilities of core need in a more targeted and predictable way.

In addition, each DPS area would set out a proportional relationship of additional height and density to community benefits received. ${ }^{14}$ Ideally, this would set into policy the idea that every neighbourhood has a different capacity for taking on additional height and density. At the very least, the language describing the OPA explicitly mentions density and the issue of legislating mechanisms to keep up with growth, which is a progressive and long overdue step according to many (Gee; Lorinc; Chakrabarti).

\section{Development Permits System - A Shift in Instrumental Power}

Finally, any the DPS works to limit the short-sightedness of ward politics in the development process. While the current system of ward councillor negotiated development approvals can have advantages in its flexibility and ability to leverage, political interests and lack of legislative guidance dilute its ability to respond to needs in coordinated way that flows from the interests of community members (Costello \& Longo, 2013). In this way, it can be argued that the DPS is progressive in that it ideally gives more weight to ideas of what the area should look like in the long

\footnotetext{
14 The Section 37-like process in the DPS is a move toward a formula-based calculation of benefits (as seen in Vancouver), as opposed to the current negotiation-based system.
} 
term by taking steps limit the unpredictable and volatile nature of political priorities and election cycles.

In urban planning, the weakening of executive power of politicians means gains in power elsewhere, and the DPS is no exception. ${ }^{15}$ Though elected officials will be heavily involved in the shaping of the DPS area plan, once it is in force, all third parties will not have appeal rights. This means that any contentious applications will be dealt with by planning staff, representing a significant shift in planning power. Further, under the DPS, council now has the option to delegate approval authority to a committee or city employee - which the OPA recommends to be the Chief Planner (City of Toronto, Nov.6, 2013). As planners gain more discretionary power while councillor and OMB influence on individual applications is much more limited, there is a fear that staff may make overly technical and 'rational' decisions that are not representative of plans set out by the community, or make become too enmeshed with developer interests (Sewell, 1995). This concern is somewhat assuaged by the need for council approval, yet under the DPS council can also delegate approval to city staff. This shift of power towards staff and away from third parties only begins with councillors and the $\mathrm{OMB}$ - the main challenge that this fundamental systemic change in planning will need to address is the role of the public.

\section{Development Permits System - Major Critiques}

Reviewing initial messaging rolled out City of Toronto (OPA, slide deck and consultation handouts) the material fails to squarely address the elephant in the room - the removal of appeal rights for third parties. The slide presentation gives scant attention to the issue - it is mentioned once, and does not have its own explanatory slide - and the OPA commits a surprisingly small amount of discussion to it. However, at the Reset TO public meeting it was made clear during a question

\footnotetext{
15 Forester (1989) argues that the natural source of planning power comes from control of information. As city staff would control information on proposals and have increased discretionary power, critics could make the case that under the DPS, planners gain power for themselves as opposed to empowering citizens.
} 
period that the OMB would not be able to approve above height limits - a key feature that has not been clearly communicated so far.

Regardless of the stronger height caps, lack of third part appeals presents problems on several levels. On a general level, the public has the expectation that it should have a voice on significant developments, and appreciates an appeal mechanism if it feels that good planning principles have not be adhered to (Nethery, 2011, p. 13). Next, there is the fear that once implemented, the DPS by-laws will not be flexible enough to respond to changing community interests. Although City staff can initiate a by-law review process if they feel that goals and objectives have changed, critics could warn against the increased discretionary power in the hands of planners and experts.

Another point of contention looks to the structure and breadth of consultation. Initially, only two meetings were proposed to deliberate over the complexities of massing, public realm, height-ranges, design, character, heritage, and begin discussions around community benefits, services and infrastructure requirements (City of Toronto, November 6, 2013). The City has since clarified that the process would involve more than two meetings. However to expect these complex issues to be given adequate information and deliberation in a series of public meetings is a concerning logistical challenge. Further, as theorists like Fainstein and Healy remind us, people do not have fixed interests - they change their minds according complex motivations (Fainstein, 2000, p.457). The removal of an ongoing appeal right could incite discontent over a perceived lack of ongoing input. Also, given the threat of extremely high mobility among Downtown demographics, there is no guarantee that the communities who shape DPS priorities will be around to feel their impacts at work.

Another potential concern is related to NIMBY, in that citizens may seek to deliberately "down zone" the height ranges on local DPS area plans in order to 
discourage development, no matter how appropriate. ${ }^{16}$ Demonstrated in a study of massive rezoning initiatives in New York City, areas that were successful in exerting public pressure to down-zone were predominantly white, with higher incomes and higher rates of homeownership as compared with up-zoned areas (Laskow, 2014). How areas are selected for DPS by-laws and on what basis is not yet known, but will surely have implications for NIMBY and gentrification.

\section{The Development Permits System and Quality of Life}

As an alternative planning tool, the Development Permits System represents a significant opportunity to improve quality of life for people living in high-density communities in the Downtown. It does so through the following:

1. Places greater importance on vision for neighbourhoods as a whole and ideally enables citizens to play a central role shaping this vision.

2. Better potential to safeguard community interests through more stringent processes to build above as-of-right. Represents a stronger policy mechanism to protect local character and distinctiveness.

3. Ties data on existing conditions and community priorities to the ability to accommodate growth and change from an infrastructure perspective.

4. Development criteria must be met in order for a permit to be issued, allowing DPS to orchestrate identified quality of life objectives in future development.

On the first point, the DPS represents a classic shift in the theoretical underpinnings of urban planning. The current site-by-site zoning system is aligned with Lindblom's idea of the planner as incrementalist. Currently, the system of approvals exhibits a limited and tenuous understanding of capacity and broader contextual impacts - so we 'make do' with the information we have. Given that the information available is limited, planners must work within a 'bounded rationality' to negotiate the best we

\footnotetext{
16 It could be argued that the overall intent of a DPS is to set new rules on development that must be respected. Part of this would be to presumably to 'up-zone' many areas to reflect current conditions and to simultaneously set limits on it. However, neighbourhoods may attempt to 'freeze' their areas at the lowest densities possible in order to limit any perceived impacts on them. This would go against the intention of the DPS to modernize, update and reset the planning framework.
} 
can to serve and support new growth through processes like Section 37 (see Forrester, 1984, p.24). The DPS enables the Downtown to move forward from this by shaping our longer-term outcomes in a more proactive way through area studies. This information and consultation based approach will enable communities to rely less on 'satisficing' and more on planning approaches that are more expressly linked to data and infrastructure priorities. Clearly articulated neighbourhood visions allow for people to better understand the big picture of development and how it should satisfy the priorities and challenges of their communities, and the DPS makes clear strides toward this.

On the second point, the fact that OMB cannot approve height and density above the height ranges set out in the conditions of a DPS by-law has the potential to better link community priorities with longer-term built form outcomes. This goes back to Brooks' idea of local communities standing for a 'third system' of power, along with government and the market (Brooks, 2002). Under the DPS, this third system's (the community) claim to power is strengthened in that the OMB and council must adhere to the criteria and conditions around built-form. In an ideal scenario, DPS bylaws allow urban growth to conform to the articulated needs of the community first and foremost, as the amendment process for additional height and density would be a much more rigorous process under this system.

On the third and final point, DPS background studies are designed to link development impacts proportionally to a prioritized list of community benefits. This process has the potential to better coordinate community benefits to mitigate the effects of growth in the long term. It is worth noting that very little has been done on the economics of this approach so far (City of Toronto, 2014 Reset TO consultation), so we cannot assume that benefits will be an adequate source of revenue for doing so. We can say that benefits are better targeted and more transparent under this system. To urban theorists like Armour (1995) background studies like those in the DPS represent safeguards the quality of life of the 
community by ensuring that compensation from development pressure is directly linked its impacts on people.

The final point speaks to the idea that development criteria (a suite of design and landscape criteria) for the entire site must me adhered to. This holds potential for promoting a greater range of housing options discussed in Section 1. It could also require targeted and specific improvements to the public realm based on findings from the public realm assessment tool discussed in Section 2. A DPS framework could better ensure that specific quality of life objectives such as these are addressed.

Overall the DPS as proposed so far adheres to Short's comprehensive international review of planning strategies to address height and density:

The adoption of specific policies and guidance documents in support of the development plans should allow locally-based tall building solutions to evolve which reflect local concerns, and offer greater scope for them to be both appropriately cited and reflective of community and stakeholders opinions. (2012, p.192)

It must be recognized that success of the DPS is hinged on the process of creating area by-laws. Currently, the proposed policy is not at the stage where it identified how the process would work, but suffice to say, a meaningful process will be very difficult to implement. Achieving the right balance of interests that live up to the expectations of this approach will be a daunting undertaking. In particular, it will be a hard balance to achieve a consensus between height-averse residents and a development community that has enjoyed a system based on exceptions. However, as DPS plans are essentially a policy-strong relative of secondary or site specific plans, the City can draw on the lessons learned from more successful examples (e.g Lawrence-Allen Secondary Plan) and tailor them to an approach that works for the intentions of the DPS.

\section{Section3 - Recommendations:}


Although many features of the DPS draw criticism, it represents a progression from the current system of reactionary, site-by-site planning. This is not to say that it is appropriate everywhere. The entirely voluntary nature of this system as a planning tool is all the more reason to promote it as another possible strategy for communities to better manage growth and increase quality of life for residents. The following refinements to the DPS moving forward would serve to strengthen its potential, while mitigating its shortcomings where possible:

1. Improve clarity around how the DPS works, as it is a complex idea that requires a baseline of understanding for buy-in. A study of uptake of the DPS throughout Ontario found the main reason for its relative lack of uptake is was lack of knowledge of the system on the part of planners, politicians and the private sector (Nethery, 2011, p.47). This means outlining the contentious aspects of the DPS - mainly removal of appeal rights - in a straightforward manner, specifying that OMB cannot approve anything outside its standards.

2. Slow down the implementation of the DPS especially around the fast tracking of permit approvals. Emphasis should shift away from expediting the development process and concentrate instead on a fulsome strategy for the front-ended consultations to shape the by-law priorities. This could include a predictable series of meetings based on specific issues (at least 4 or 5 sessions). By taking a measured approach to community input and backing off on unreasonable 45-day review periods, the DPS would increase buy-in prioritizing resident input ahead of development interests.

3. Make the DPS more responsive to dynamic demographic change. A mechanism should be built into a by-law that is linked to mobility trends. If an area is seeing very high mobility above a certain threshold, the policy should trigger a By-law review process to ensure that the DPS is still representative of new neighbourhood resident priorities.

4. To chose Pilot areas for DPS by-laws strategically. DPS by-laws should first be tested in areas where large-scale development is putting pressure on the scale of existing conditions, such as the areas where the neighbourhoods and apartment neighbourhoods abut mixed use areas in the OP. ${ }^{17}$ DPS is also applicable to lower scale neighbourhoods that may be able to accommodate very specific types of higher-density, yet lower scale development consistent with neighbourhood character. At this stage in its development, the DPS may

\footnotetext{
17 Examples include the Church Wellesley neighbourhood and areas near College and Spadina, where large-scale residential developments are beginning to 'creep' into lower scale neighbourhoods or special character areas.
} 
not be flexible enough respond to fully built-out and extremely dynamic high growth Downtown areas like King-Spadina, and may be better suited to contexts looking to up-zone rather than down-zone.

5. Ensure community benefits are selected realistically, as the mature urban fabric of the Downtown is constrained in the types of benefits that can be provided. This could include more cash-in-lieu benefits.

6. To clearly link DPS development criteria to quality of life outcomes. The background studies need identify development criteria that promotes a greater range of housing options, invests in the surrounding public realm and responds to the priorities expressed by residents. 


\section{Conclusion}

This discussion broadly considered quality of life in the context of development trends in Downtown Toronto. Early on, we considered Michael Short's question: Is surrounding communities? Taking all three sections together and the recommendations therein, we can tenuously answer this question. As one of the fastest growing urban areas in the world, the Downtown is facing incredible pressure that represents a threat to current and future residents and its own sustainability. The City has since been moving to strengthen its policy framework to manage this growth effectively. This has meant a shift toward a more prescriptive approach to planning.

The Development Permits System shows significant potential to better manage growth and tie new development to targeted infrastructure contributions. DPS also affords communities with the appropriate tools to require that the type of growth we see meets the priorities of residents and maintains a high quality of life for residents. We discussed two examples - promoting a full range of housing (Section1) and a tool to identify key investments to the public realm in order to support growth (Section 2).

While it holds potential, it should be recognized that the DPS is not appropriate everywhere. As the DPS many not be suited to the most dynamic, high growth areas, a suite of other approaches to regulating growth is needed. Alternatives could include updated Secondary Plans or a broader Downtown Secondary plan with stronger, more specific policy tools to regulate development. This would likely include a finer grain of guidance for the mixed-use areas, vulnerable lower-scale neighbourhoods and identified special character areas.

As the City moves forward with ever-larger scales of development, we need to pay heed to how residents perceive their own quality of life. Whether we recognize it or not, there are limits to development and the capacity to sustain growth. The further 
we go with the status quo, the less case planners and communities will have to set out a vision for the Downtown. 
Appendix 1: Public Realm Assessment Tool

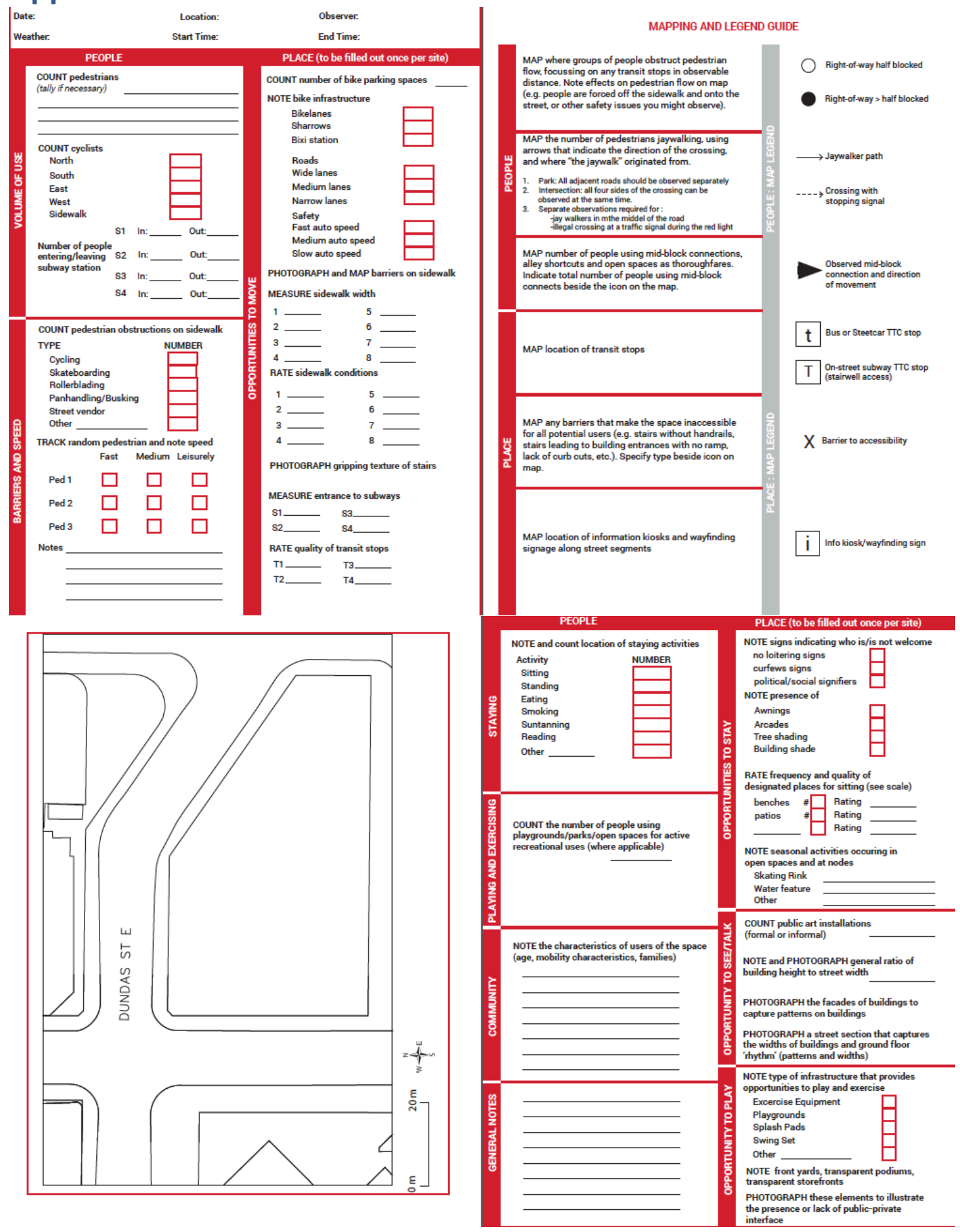




\section{References}

Amborski, D. (2011) Alternatives to Development Charges for Growth-Related Capital Costs. Report for the Residential and Civil Construction Alliance of Toronto. Armour, Audrey 1995: The Citizens' Jury Model of Public Participation: A Critical Evaluation, in: Renn, Ortwin / Webler, Thomas / Wiedemann, Peter (ed.): Fairness and Competence in Citizen Participation, Dordrecht: Kluwer, pp. 175-189.

Bascaramurty, D. (2012) Density, infrastructure and the high cost of building a vertical Toronto. The Globe and Mail. Retrieved from: http://www.theglobeandmail.com/news/toronto/density-infrastructure-and-thehigh-cost-of-building-a-vertical-toronto/article4610721/

Brooks, M. P. (2002). Planning Theory for Practitioners. Chicago, IL: Planners Press, American Planning Association.

Building Industry and Land Development Association (2014). Building Futures: An industry conversation with Toronto councillors and Chief Planner. Online blog post. Retrieved from: http://www.bildblogs.ca/building-futures-industry-conversationtoronto-councillors-chief-planner/

Canadian Institute of Planners. (2010). Canadian Institute of Planners Code of Practice.

Collins-Williams, M. (2012) The Changing Face of Urban Development in the GTA. Urban Toronto. Retrieved from: http://www.urbantoronto.ca/news/2012/02/changing-face-urban-developmentgta

Chadha, R. (2013, May 30). My condo fees are crazy: What is a reasonable rate? The Globe and Mail. Retrieved from: http://www.theglobeandmail.com/life/home-andgarden/real-estate/my-condo-fees-are-crazy-whats-a-reasonablerate/article12265036/.

Chakrabarti, V. (2013) A Country of Cities: A manifesto for an urban America. New York: Metropolis Books.

Chapman, D.W., and Lombard, J.R. (2006) Determinants of neighbourhood satisfaction in fee-based and non-gated communities. Urban Affairs Review, 41(6), 769-799.

City of Toronto (2014, March 21). Reset T0 public meeting. Toronto, Ontario. Report Pending 
City of Toronto (2014). Avenues and Midrise Buildings Study. City of Toronto City Planning Division Urban Design Website. Retrieved from: http://www1.toronto.ca/wps/portal/contentonly?vgnextoid=7238036318061410 VgnVCM10000071d60f89RCRD

City of Toronto. (2013). Profile Toronto: How Does the City Grow? City Planning Division. October edition.

City of Toronto. (2013, November 25). King-Spadina Built Form Study Public Meeting: Participant Response [Firsthand Notes]. Background info retrieved from: http://www1.toronto.ca/wps/portal/contentonly?vgnextoid=10a50621f3161410V gnVCM10000071d60f89RCRD

City of Toronto, Director, Community Planning, Toronto and East York District. Staff Report (2012, May 22) Reference Number: 11-143142 STE 20 OZ - Official Plan Amendment.

DASH Property Management (2014) Tenants: Harbour View Estates. Realty Listing Website. Retrived from: http://www.dashdevelopments.com/tenants/buildinginfo.php?35-Mariner-Terrace-54

Dempsey, A. (2010, July 4). St. James town pool sits empty. Toronto Star .

Fainstein, S. (2000). New directions in planning theory. Urban Affairs Review, 35(4), 451-478.

Forrester, J. (1984). Bounded Rationality and the politics of muddling through. Public Administration Review, January/February Edition, p.23-31.

Fleming, D. (2012, December 1). Condo amenities that aren't worth the money. The Grid

Francis, D. (2012, May 4th). Taxpayers also victims of 'hot money' behind Canada's condo bubbles. Financial Post. Retrieved from: http://opinion.financialpost.com/2012/05

Gehl, J. and Svarre, B. (2013). How to Study Public Life. Island Press: Washington.

Gilliard, B. (2013) Lessons for Toronto from Melborne's City Centre Revitalization (Major Research Paper) unpublished manusript submitted to Ryerson University.

Greenbie, B. (1981) Spaces: Dimensions of the Human Landscape. New Haven: Yale University Press.

Hanes, T. (2013, August 23). The urban townhouse comes of age. The Toronto Star. Retrieved from: 
http://www.thestar.com/life/homes/2013/08/23/the_urban_townhouse_comes_of _age.html

Hume, C. (2013, October 13). Toronto's Chief Planner, Jennifer Keesmaat, challenges Mirvish/Gehry scheme. The Toronto Star .

Innes, J. (1998). Information in communicative planning. Journal of the American Planning Association. 64(1), 52-63.

Laing, A., and Royle, J. (2013) Examining chain bookstores in the context of "third place". International Journal of Retail and Distribution Management 41(1), 27-44.

Langolis, P. (2012). Meaning, media and dwellings: the public image of the high-rise Toronto condo. (Doctoral dissertation).

Laskow,S. (2014, Feburary 24) The quiet, massive rezoning of New York. Capital New York. Retrieved from: http://www.capitalnewyork.com/article/cityhall/2014/02/8540743/quiet-massive-rezoning-new-york

Lorinc, J. (2012, October 29). Understanding the pressures of downtown development. Spacing. Retrieved from: http://spacing.ca/toronto/2012/10/29/lorinc-understanding-the-pressures-ofdowntown-development/

Marohn, C. (2013). Its about so much more than density. Better Cities and Towns online. Retrieved from: http://bettercities.net/news-opinion/blogs/charlesmarohn/19318/its-so-much-more-density

Martel, A. (2013). Getting to Yes: Overcoming barrier to affordable family housing in inner Melbourne. University of Melbourne Faculty of Architecture, Building and Planning. Getting to Yes Research Team (Whitzman, C.: Lead Investigator).

McKellar, J., and Amborski, D. (2009, January 29). Building a sustainable Toronto: Discussion paper. Retrieved from Building a Sustainable Toronto website: http://yfile.news.yorku.ca/2009/04/20/a-sustainable-toronto-requires-urbanintensification/

Moloney, P. (2013, June 25). Condo Boom: Developers say doubling development charges threatens downtown renaissance. The Toronto Star. Retrieved From: http://www.thestar.com/news/city_hall/2013/06/25/condo_boom_builders_say_d oubling_development_charges_threatens_downtown_renaissance.html

Munro. S (2014) Toronto deserves better transit now! Part 4 - Streetcar riders count too. Steve Munro (blog). Retrieved from: http://stevemunro.ca/?p=9404 
Nethery, J. (2011) Organizational behavioural obstructions between planners and implementing the development permits system. (Major Research Paper) Local Government Program, Department of Political Science, University of Western Ontario.

Keenan, E. (2014, February 21). Have you noticed it is getting really crowded downtown? So why is Adam Vaughn pushing for more? The Grid TO. Retrieved from: http://www.thegridto.com/life/real-estate/adam-vaughan/

LaRusic, E. (2013, January 20). Neighbourhood Responds to Lanterra Condo and Park Proposal. Urban Toronto. Retrieved from: http://urbantoronto.ca/news/2013/06/neighbourhood-responds-lanterra-condoand-park-proposal

ONNI (2014). Local at Fort York project website. Retrieved from: http://onnifortyork.com/local/building/

Ontario Municipal Board, (October 28, 2013). Brant Park Inc versus City of Toronto (OMB File No:PL130142). s.18-19.

Oldenburg, R. and Brissett, D. (1982) The third place. Quantitative Sociology, 5(4) 265-284.

Perkins, T. (2014, February 15). Aggressive development: Inside the building and selling of a Toronto condo tower. The Globe and Mail. Retrieved from: http://www.theglobeandmail.com/report-on-

business/economy/housing/aggressive-development-the-building-and-selling-of-atoronto-condo-tower/article16910442/?page=all

Province of Ontario. (2006). Growth plan for the greater golden horseshoe. Toronto: Ministry of Public Infrastructure Renewal.

Public Realm Studio Group (2014) Coursework for Ryerson University, School of Urban and Regional Planning. Toronto. Contributors/Members: Gordon, G., Chung, M., Bianchs, M., Kluke, J., Behrooz, S., McKinnes, C., Wolfe, C.

Pushchak, R. (2013) Lecture notes, March 25 for Theory of Design and Urban Planning, Ryerson University School of Urban and Regional Planning.

Rosen, G. and Walks, A. (2013) Rising cities: Condominium development and the private transformation of the metropolis. Geoforum 4 49, 160-172.

Searle, G., \& Filion, P. (2011). Planning context and urban intensification outcomes: Sydney versus toronto. Urban Studies, 48(7), 1419-1438. 
Sewell, J. (1995). Creating an Alternative to Modernism. In J. Sewell, The Shape of the City: Toronto Struggles with Modern Planning (pp. 173-198). Toronto: University of Toronto Press.

Short, M. (2012). Planning for tall buildings. Cornwall, Routledge.

Slack, E. (2002) Municipal Finance and the Pattern of Urban Growth. CD Howe Institute Commentary. v.160.

SWERHUN . (2013). Condominium Consultation Comprehensive Report Rounds 1 and 2. Consultants' Report, Submitted to the City of Toronto , City Planning Division Policy and Analysis.

TD Economics (2013). "Toronto: A Return to the Core" Observation Series. Retrieved from: http://www.td.com/document/PDF/economics/special/ff0113_toronto.pdf

Velaja, P. (2012, July 2) The Manhattanization of Toronto will change family-housing dreams. $\quad C B C$ Retrieved from: http://www.cbc.ca/news/canada/themanhattanization-of-toronto-will-change-family-housing-dreams-1.1137590

Warner, M. E. (2011). Club Goods and Local Government: Questions for Planners. Journal of the American Planning Association, 77 (2).

Urban Strategies. (2013) Alexandra Park Urban Design Guidelines, Submitted to the City of Toronto and Toronto Community Housing. Retrieved from: http://www1.toronto.ca/wps/portal/contentonly?vgnextoid=a3c30621f3161410V gnVCM10000071d60f89RCRD

Urbanation. (2012, November 4). Assignment Survey Cancelled: Urbanation Blog. Retrieved from: http://urbanationinc.blogspot.ca/2012/11/assignment-surveycancelled.html

\section{Image Credits}

Image 1: Untitled (2013) City of Toronto Tall Building Design Guidelines. P.44

Image 2: Untitled (2012) Entertainment District Business Improvement Association Entertainment District Masterplan. Retrieved from: http://torontoed.com/home (under the 'plans and reports' heading). 